\title{
Diatom flora in subterranean ecosystems: a review
}

\author{
E. Falasco*1, L. Ector ${ }^{2}$, M. Isaia ${ }^{1}$, C.E. Wetzel ${ }^{2}$, L. Hoffmann ${ }^{2}$, and F. Bona ${ }^{1}$ \\ ${ }^{1}$ Life Sciences and Systems Biology Department (DBIOS), University of Turin, Via Accademia Albertina 13, I-10123 Turin, Italy \\ ${ }^{2}$ Department of Environment and Agro-biotechnologies (EVA), Public Research Centre - Gabriel Lippmann, Rue du Brill 41, L-4422 Belvaux, Luxembourg
}

\begin{abstract}
In scarcity of light and primary producers, subterranean ecosystems are generally extremely oligotrophic habitats, receiving poor supplies of degradable organic matter from the surface. Human direct impacts on cave ecosystems mainly derive from intensive tourism and recreational caving, causing important alterations to the whole subterranean environment. In particular, artificial lighting systems in show caves support the growth of autotrophic organisms (the so-called lampenflora), mainly composed of cyanobacteria, diatoms, chlorophytes, mosses and ferns producing exocellular polymeric substances (EPSs) made of polysaccharides, proteins, lipids and nucleic acids. This anionic EPSs matrix mediates to the intercellular communications and participates to the chemical exchanges with the substratum, inducing the adsorption of cations and dissolved organic molecules from the cave formations (speleothems). Coupled with the metabolic activities of heterotrophic microorganisms colonising such layer (biofilm), this phenomenon may lead to the corrosion of the mineral surfaces. In this review, we investigate the formation of biofilms, especially of diatomdominated ones, as a consequence of artificial lighting and its impacts on speleothems. Whenever light reaches the subterranean habitat (both artificially and naturally) a relative high number of species of diatoms may indeed colonise it. Cave entrances, artificially illuminated walls and speleothems inside the cave are generally the preferred substrates. This review focuses on the diatom flora colonising subterranean habitats, summarizing the information contained in all the scientific papers published from 1900 up to date. In this review we provide a complete checklist of the diatom taxa recorded in subterranean habitats, including a total of 363 taxa, belonging to 82 genera. The most frequent and abundant species recorded in caves and other low light subterranean habitats are generally aerophilic and cosmopolitan. These are, in order of frequency: Hantzschia amphioxys, Diadesmis contenta, Orthoseira roeseana, Luticola nivalis, Pinnularia borealis, Diadesmis biceps and Luticola mutica. Due to the peculiarity of the subterranean habitats, the record of rare or new species is relatively common. The most important environmental factors driving species composition and morphological modifications observed in subterranean populations are analysed throughout the text and tables. In addition, suggestions to prevent and remove the corrosive biofilms in view of an environmentally sustainable cave management are discussed.
\end{abstract}

Keywords: $\quad$ artificial lighting; Bacillariophyceae; cave; corrosion; lampenflora

Received 9 December 2013; Revised 24 February 2014; Accepted 2 March 2014

Citation: $\quad$ Falasco E., Ector L., Isaia M., Wetzel C.E., Hoffmann L. and Bona F., 2014. Diatom flora in subterranean ecosystems: a review. International Journal of Speleology, 43 (3), 231-251. Tampa, FL (USA) ISSN 0392-6672 http://dx.doi.org/10.5038/1827-806X.43.3.1

\section{THE SUBTERRANEAN ENVIRONMENT}

Natural sciences (from Earth to biological sciences), medical sciences, engineering and the cultural history of mankind find in caves an imaginary crossroad, where different disciplines meet enhancing our understanding of the history of our planet. Research into the biology of caves is not only a matter of exploring unique and extreme ecosystems, but is also fundamental to our understanding of the delicate ecological balances on Earth (Lee et al., 2012).

When compared with surface ecosystems, subterranean environments often have a low abundance and diversity of organisms (Holsinger, 1998) and the abiotic conditions at the deeper parts of the caves are generally more stable. In the absence of light and primary producers, cave habitats are generally extremely oligotrophic, receiving poor supplies of degradable organic matter. They rely almost exclusively on organic matter from surface habitats (Poulson \& Lavoie, 2000). Primary source of energy is generally decaying organic matter deriving from plants, guano and carrion (Braack, 1989), whose bioavailability is largely dependent on its chemical properties and on environmental physical factors, such as temperature and light (Smith \& Benner, 2005). 
A few species of bacteria, fungi and protozoa rely on other sources of energy, including inorganic compounds of sulphur, ammonium and ferrous iron. Because of their long isolation from the surface and because of the scarcity of nutrients, some subterranean microbes appear to have evolved the capacity of producing specialized chemical compounds, or toxins, with which to fend off competing microbes. This is the case of a group of chemolitotrophic bacteria discovered by Haak et al. (2002) in the deepest part of the Mammoth Cave (Kentucky, USA), which produce a compound with a supposed anti-cancer activity.

All kinds of life forms (i.e. viruses, bacteria, fungi, algae, protozoa, plants, animals) have been found in a range of different types of subterranean habitats, especially within caves, in pools, on rocks, in springs, on cave walls or even dispersed in the air (Culver \& Pipan, 2009; Romero, 2009). Cave biological communities are generally characterized by a co-presence of resident and non-resident organisms (accidentals) (Culver \& Pipan, 2009). Accidentals enter caves occasionally via water, sediments, wind or air, as spores, or can even be carried in by animals, including men.

Depending on their actions and length of stay in the cave, accidentals may have dramatic effects on the resident "true" troglobiont populations and, in the worst-case scenario, they may even displace the original populations and communities (Saiz-Jimenez, 2010). However, as soon as any subterranean habitat is disclosed and connected with the surface environment, the ecosystem becomes subjected to an unaccustomed and relatively large input of organic matter, or may be impacted by invading communities coming from the surface (Lee et al., 2012).

The potential human impacts on subterranean ecosystems can be broadly divided into external and internal ones (Gunn et al., 2000). External impacts such as pollution or quarrying usually pose serious problems, potentially altering sediment loads, subsurface hydrology and both clastic (sediment) and chemical water quality (Watson et al., 1997). Internal impacts mainly derive from recreational caving and intensive uncontrolled tourism, resulting from inappropriate lighting and the presence of visitors, causing changes in the relative humidity, temperature and carbon dioxide concentration in air, as well as alterations of the optimal living conditions of the subterranean biological communities. All these effects would bring about a gradual decline of the environmental quality, favouring the degradation of cave art, biodiversity (Mann et al., 2002) and speleothems (Baker \& Genty, 1998). A speleothem is defined as a secondary mineral deposit formed in a cave (i.e. stalactites, stalagmites, flowstones, stone waterfalls and pillars) (Moore, 1952).

However, the strongest disturbance recorded so far has been by commercial cave mass tourism, which began during the second half of the 19th century. At that time, minimal consideration was given to conservation and practices adopted for cave visiting often resulted in irreversible damages caused by visitors, mostly in terms of lint, litter, increased carbon dioxide from exhaled breath and increased temperature levels due to human body heat.

Moreover, artificial lighting in relation to touristic exploitation of show caves (i.e. caves made accessible to general public) is sufficient to support the growth of various phototrophs that would otherwise not be able to survive. The so-called lampenflora is a complex of autotrophic organisms colonising illuminated cave walls leading to the formation of green-brown patinas (Jones, 1965; Grilli Caiola et al., 1987; Hoffmann, 1989; Bertolani \& Cigna, 1993; Passauer, 1996; Compagnone et al., 1999; Hoffmann \& Darienko, 2005; Bruno et al., 2006, 2009; Lamprinou et al., 2011). The term lampenflora - used for the first time by Dobat (1963) to describe the proliferation of phototrophic organisms near artificial light sources - is an originally German term used in the English vocabulary. Lamp flora in English or maladie verte in French are sometimes used as synonyms (Mulec, 2012).

The formation of lampenflora is an important and well-studied phenomenon usually driven by light intensity and quality as well as light time schedule (Rajczy et al., 1984; Roldán \& Hernández-Mariné, 2009) of the artificial illumination system. Photon flux density can reach high values but the peaks of the light spectra can be reduced at some wavelength (Albertano, 1993). In show caves, in particular, the photosynthetically active radiation (PAR) is the limiting factor for autotrophic organisms and the key factor determining the formation of autotrophic (i.e. eukaryotic algae and cyanobacteria) or heterotrophic (i.e. fungi and bacteria) biofilms (Roldán \& Hernández-Mariné, 2009). Among eukaryotic microalgae, the most important groups are Chlorophyceae and Bacillariophyceae (diatoms), of which little is known in comparison to the number of studies carried out on those that live in aquatic environments such as rivers, lakes and oceans.

This review synthesises literature data on diatoms colonising subterranean habitats, especially caves but also other underground environments that have been studied for their historical and cultural significance. In this regard, the term "subterranean habitats" is also used when referring to subterranean sites other than caves (either artificial or natural), such as catacombs, mines and ice caves (i.e. caves that contain seasonal and/or perennial ice; Balch, 1900). We analysed more than 190 articles published from 1900 to date encompassing the algal flora of more than 140 subterranean sites; within them, we particularly focused on papers concerning diatom flora. In addition to the floristic data, we analysed the main environmental factors reported as affecting the species distribution, including artificial lighting in show caves. With this regard, the main environmental issues related to the formation of autotrophic biofilms on speleothems are presented. 
BIOFILM FORMATION AND ITS IMPACT ON SPELEOTHEMS

Whenever sufficient light is available, phototrophic organisms are able to colonise almost any kind of substrate. As little as 1 umol photon $\mathrm{m}^{-2} \mathrm{~s}^{-1}$ may already be sufficient to support their growth (Grobbelaar, 2000).

In illuminated subterranean habitats, cyanobacteria, diatoms and chlorophytes generally colonise illuminated walls in form of biofilms causing aesthetic, physical and chemical damages (Albertano et al., 2003). Usually epilithic cyanobacteria and chlorophytes are the first colonizers (Albertano, 1993) and cyanobacteria play a key role in the genesis of biofilms, being able to produce exopolymeric substances (EPSs) that allow the adhesion to rocks and the consequent establishment of a microbial community (Stal, 2000). Thanks to EPSs the cells stick to the walls and incorporate inorganic matter, bacteria and airborne particles (Albertano et al., 2003). As a consequence they provide a thin and sticky layer rich in nutrients that retains humidity and stabilizes the biofilm (Albertano, 1993). EPSs (polysaccharides, proteins, lipids and nucleic acids) promote ion absorption and regulate calcification processes and are generally produced against desiccation, toxic substances and UV radiation (Bellezza et al., 2003, 2006; Albertano et al., 2005). The anionic EPSs matrix mediates to the intercellular communications and participates to the substrata exchange (Hoffmann, 2002). The structure of the biofilm is generally related to the availability of light: close to the cave opening it is usually characterized by a series of thick layers, with diatoms on top. Thickness decreases proportionally with the light decrease and its structure becomes patchy (Hernández-Mariné et al., 2003; Roldán et al., 2004; Roldán \& Hernández-Mariné, 2009; Zammit et al., 2011). In the Puigmoltó sinkhole (Spain) Hernández-Mariné et al. (2001) noticed that the biofilm covering cave walls appeared patchy and lax as far as light intensity decreased; in the same way, also biodiversity decreased and community composition shifted towards highly specialized organisms.

The first visible damage caused by biofilms on speleothems is aesthetical (e.g. stone waterfalls); algae are extremely successful in colonising illuminated areas and discolour speleothems, giving them a dirty and unsightly appearance. Similarly, biofilms cause serious damages to cave paintings. A well-known case of damage is caused by Bracteacoccus minor (Chodat) J. Petrová, a green alga growing on the prehistoric wall paintings of the world famous Lascaux Cave, France (Lee et al., 2012). Also in Tito Bustillo Cave (Spain), the green colour of speleothems near the lighting lamps is remarkable. There, the dominant microbial community is composed of calcifying cyanobacteria that are able to precipitate calcium carbonate in the external sheath (Ariño et al., 1997). Moreover, algae and mosses are associated in contributing to the damage.

Secondly, the growth of biofilm leads to structural damages (chemical alteration like dissolution and mechanical breakdown) of the substrate, as highlighted by many authors (e.g. Cañaveras et al., 2001; Hoffmann, 2002). This is mainly a consequence of $\mathrm{CO}_{2}$ uptake and $\mathrm{CaCO}_{3}$ dissolution. Moreover, respiration processes and the consequent production of carbonic acid lead to the corrosion of cave formations, with irreversible consequences (Smith \& Olson, 2007). Microbial groups forming biofilms on cave walls can have both a constructive and destructive role on lithic surface. EPSs favour the trapping and binding of detrital grains, the precipitation of calcite and contribute to cave biogenesis (Riding, 2000). Cheeptham (2013) suggests that biofilms contribute to the genesis of different kinds of speleothems, such as stalactites, stalagmites, pool fingers, cave pisoliths and moonmilk. Some diatoms, such as Melosira (Kashima et al., 1987), Aulacoseira, Neidium, Odontidium, Sellaphora, Stephanodiscus, and Synedra (Vidal Romaní et al., 2010) are known to be part of coralloid speleothems in non-calcareous caves or in travertines (Pentecost, 1998). The formation of these elements, indeed, can be triggered, directly or indirectly, by diatom activities (Kashima et al., 1987). Microbes can become part of the speleothems through calcification and precipitation processes of minerals on their external surface. Moreover, the biological origin of several speleothems has been recently hypothesised: microorganisms living in crevices can be considered part of their structure acting as sedimentary traps for the mobilised materials (Vidal Romani et al., 2010). The microbial processes in caves often involve redox reactions (Sasowsky \& Palmer, 1994; Barton \& Northup, 2007) that modify microenvironmental conditions. Growth of photo- and hetero- trophic organisms can have a synergic effect in the speleothems deterioration. Indeed, organic matter produced by autotrophs is necessary for fungi and bacteria to produce acid organic compounds which solubilise the minerals of the substratum. Precipitation of mineral particles on sheaths can shift strains from epilithic to endolithic colonization (Asencio \& Aboal, 2001). The same phenomenon has been observed after the exposure to high light intensities. This may change the mineral structure of the rock determining its decay. Erosional processes by microbial activity induce the breakdown of rock substrate, recycling essential nutrients, such as carbon, nitrogen, sulfur and phosphorus. In subterranean environments, a variety of precipitation and dissolution processes may occur. Bacteria produce enzymes, organic and mineral acids (such as sulfidric acid) inducing corrosion or dissolution of mineral surfaces (Northup \& Lavoie, 2001). The cyanobacterial sheaths play an important role in the rock breakdown because they can absorb and release large quantities of water, thus changing the mineral structure of the rock, with subsequent destruction, weathering and increased porosity.

The EPSs produced by the biofilm can be negatively charged (due to uronic acids and sulphated groups) inducing the adsorption of cations and dissolved organic molecules from the mineral surface (Hoffmann, 2002; Albertano et al., 2003). This phenomenon coupled with the metabolic activities of microorganisms colonising the layer leads to 
the corrosion of the mineral surfaces (Albertano \& Bellezza, 2001). Calcium ions can be adsorbed from the rocks and precipitate in the EPS matrix as calcium carbonate. In the same way nitrogen and phosphorus can be taken up and stored in cells (Albertano et al., 2003). Bacteria and fungi forming the biofilm produce acidic organic compounds as final products, leading to the corrosion of the colonised substrate (Albertano \& Urzì, 1999). Value of $\mathrm{pH}$ increases as a consequence of photosynthetic activities, inducing a change in the solubility of the mineral substrate and leading to the corrosion of the surface (Albertano et al., 2000).

\section{ECOLOGY OF DIATOM ASSEMBLAGES IN SUBTERRANEAN ENVIRONMENTS}

Human impacts altering the natural light gradient in subterranean ecosystems may have important repercussions on the composition of biotic communities inside the caves. In this context, lampenflora can be regarded as invasive (Mazina \& Maximov, 2011). Tourists entering subterranean ecosystems are responsible of algae transportation (Grobbelaar, 2000; Mulec \& Kosi, 2009; Norbäck Ivarsson et al., 2013), leading to unintentional biological pollution and favouring, at the same time, the colonization of bacteria and fungi (Albertano et al., 2003). As a consequence, the alteration of the natural environmental conditions in show caves may also modify the diatom communities. Mulec \& Kosi (2009) demonstrated that lampenflora does not grow at a very close distance from incandescent lights due to high temperature. Moreover, the artificial illumination also influences the water content of the substrate (substrate moisture) and air (relative humidity). Tourist presence leads to the increase of both temperature and $\mathrm{CO}_{2}$ concentration inside the cave (Grobbelaar, 2000; Hoffmann, 2002), intensifying wall corrosion (Mulec $\&$ Kosi, 2009). Despite such peculiar conditions may allow the colonization of tropical species (Roldán \& Hernández-Mariné, 2009), most of the diatom species found in subterranean systems are cosmopolitan (Roldán \& Hernández-Mariné, 2009).

Diatoms are generally considered accidental organisms (trogloxenic according to Couté \& Chauveau, 1994) that mainly enter the subterranean environment through air circulation. In natural conditions, the abundance of algae is closely dependent from light availability and their presence would be limited to the liminar and subliminar zones. Despite this, the algal "darkflora" raised interest in the scientific community starting from 1950, and it was proven that several algal strains were able to survive in total darkness conditions (Buczkó \& Németh, 2009). The size of the cave has important effects on air circulation, and consequently on the diatom biodiversity at the deeper zones of the caves, if illuminated (Lauriol et al., 2006). Warm air, especially during summer, blows through the main entrance of the cave transporting diatoms from the surface. Diatoms generally deposit on cave speleothems consequently to air condensation on the walls (Kol, 1957; Dobàt, 1970; Lauriol et al., 1995, 2006; Mulec \& Kosi, 2009). Water circulation also plays an important role in the cave colonization. Fissures among rocks (Kol, 1957; Dobàt, 1970) as well as hypogean streams (Kawecka, 1989) may substantially contribute to the process of colonization. Species entering the cave via water are generally adapted to oligotrophic conditions.

Diatom diversity is generally related to the distance from the entrance. Liminar and subliminar zones of caves usually host the richest diatom communities, probably in relation to the influence of the external conditions and their daily and seasonal fluctuation (Hoffmann, 2002; Roldán et al., 2004; Mulec \& Kosi, 2008; Mulec et al., 2008). At small scales, rock surfaces are so extremely structurally and morphologically heterogeneous, that diatom communities colonising nearby patches can be very different (Lowe et al., 2007; Lowe, 2011). In some cases, communities are astonishingly diverse (Rushforth et al., 1984). Accordingly Smith \& Olson (2007) highlighted a remarkable trend toward sitespecificity, with more than $50 \%$ of the recorded taxa found at few sampling stations. Assemblages in subterranean environments can be very different, within the same cave, even from gallery to gallery (Darienko \& Hoffmann, 2006) and the environmental features driving species composition and relative abundances within them are still not clear.

Changes in diatom composition and richness are related to light (Patrick, 1948) and humidity fluctuation, but it is not possible to exclude the role of substratum coherence and interspecific competition (Roldán et al., 2004). Light is important and can be related to cave community diversity: show caves, closed to public for a certain period (and consequently dark for several months), have lower taxa richness than those opened and illuminated all over the year (Dayner \& Johansen, 1991). In general, wet and fully illuminated surfaces, with a significant presence of mosses are richer in diatoms than less illuminated and dry sites (St. Clair et al., 1981; Altieri et al., 1993). Even within the same cave and with a comparable illumination system, the greatest diatom diversity occurs at the moistest and most illuminated sections (St. Clair \& Rushforth, 1976). Kawecka (1989) observed the presence of several diatom species colonising a stream flowing into a cave, through a light gradient. Despite a part of the river flows in complete darkness, the author was able to find living cells of Diatoma hyemalis (Lyngbye) Heiberg, Encyonema ventricosum (Kützing) Grunow in Schmidt et al. and Fragilaria arcus (Ehrenberg) Cleve. Kawecka (1989) did not provide information on the permanence of these cells inside the dark part of the cave and did not exclude the drift from upstream sites. In general, the darkest areas of a cave can be characterized by dead or senescent individuals (such as Diadesmis and Nitzschia species) (Roldán \& Hernández-Mariné, 2009).

Beside the proximity of sites to the cave entrance, other authors observed the importance of the mineral availability on formation of lampenflora (St. Clair \& Rushforth, 1976; St. Clair et al., 1981). Indeed, beside light and humidity, also the chemical composition of 
the rock influences diatom community composition and diversity. $\mathbf{p H}$ also shapes the species composition of the communities: for instance, Diadesmis gallica W. Smith and D. laevissima (Cleve) D.G. Mann in Round, Crawford \& Mann are linked to neutral-alkaline caves while Diadesmis contenta (Grunow ex Van Heurck) D.G. Mann in Round, Crawford \& Mann and Eunotia exigua (Brébisson ex Kützing) Rabenhorst can be found in acid seeps (Poulíčková \& Hašler, 2007). According to Selvi \& Altuner (2007), in some caves low diatom biodiversity and density could be related to the lack of silica. Biofilm preferentially colonises calcite and gypsum substrata; microscopical features (e.g. roughness) of the walls play an important role (Zammit et al., 2011). Clean and smooth limestone resists to autotrophic colonization in a stronger way if compared to softer and heterogeneous clay surfaces (Rajczy, 1989; Rajczy \& Buczkó, 1989). In general, algal colonizers prefer porous, light and soft substrata (Hernández-Mariné et al., 2001; Darienko \& Hoffmann, 2006) probably because they provide higher moisture storage than compact ones (Aley, 2004).

Smith \& Olson (2007) highlighted a general trend in the increase of algal biodiversity with the increase of temperature, while a positive correlation between community richness and moisture content, up to no diatoms on dry walls, has been noticed in some cases (Pouličková \& Hašler, 2007; Czerwik-Marcinkowska \& Mrozińska, 2011). Trickling and moist sites can be easily colonised by Nitzschia sp. and Pinnularia borealis Ehrenberg (Czerwik-Marcinkowska \& Mrozińska, 2009).

\section{DIATOM ASSEMBLAGES IN SUBTERRANEAN ENVIRONMENTS: SPECIES COMPOSITION}

Diatom communities in caves are mainly composed of euaerial and pseudoaerial taxa (see Johansen, 1999 for a definition), generally characterized by small size, high resistance to desiccation, specific preferences for $\mathrm{pH}$ and tolerating low nutrient levels and high conductivity. Most of these taxa belong to the genus Navicula s.1. Cave walls generally host aerophilous diatom flora that can survive in low light conditions, e.g. troglophilic taxa (such as Hantzschia amphioxys and Luticola nivalis (Ehrenberg) D.G. Mann in Round, Crawford \& Mann); no troglobiont diatom species (obligatory occupants of the subterranean habitats that could not live elsewhere) has ever been recorded (Hoffmann, 2002). The most abundant and frequent species can be considered as cosmopolitan and distributed worldwide in the same conditions. Obviously, exceptions occur. Table 1 (available online at $\quad$ http://dx.doi.org/10.5038/1827-806X.43.3.1) offers an overview of the cave ecosystems explored from 1900 up to date and interested by diatom flora colonization.

Aerial diatom species adapted to low nutrient levels and high conductivity (Luticola nivalis, L. mutica (Kützing) D.G. Mann in Round, Crawford \& Mann) are typical of subterranean systems (Germain, 1935; Bahls, 1981; Ariño et al., 1997; Lauriol et al., 2006; Poulíčková \& Hašler, 2007; Selvi \& Altuner, 2007; Mulec et al., 2008; Czerwik-Marcinkowska \&
Mrozińska, 2009, 2011; Škaloud, 2009; Vinogradova $\&$ Mikhailyuk, 2009). Wall surface pH can influence diatom species composition: acid rocks usually host Eunotia or Pinnularia species (such as P. borealis), while Orthoseira roeseana (Rabenhorst) O'Meara is typical of alkaline substrates (Pouličková \& Hašler, 2007). Mosses and ferns can hold populations of Diadesmis gallica and Orthoseira roeseana (Roldán \& Hernández-Mariné, 2009), but also Hantzschia amphioxys, Luticola mutica and Pinnularia borealis are common as epiphytic diatoms (Poulíčková \& Hašler, 2007).

It has been unpredictably observed that some planktonic species are frequently part of the diatom communities of the cave walls (Claus, 1955, 1962b; VanLandingham, 1965; Barr, 1968; St. Clair \& Rushforth, 1976; Bahls, 1981; Lauriol et al., 2006; Poulíčková \& Hašler, 2007; Smith \& Olson, 2007; Abdullin, 2009, 2011; Buczkó \& Németh, 2009; Škaloud, 2009; Vidal Romaní et al., 2010). For instance, this is the case of Mammoth Cave (VanLandingham, 1965), in which the presence of planktonic species could be explained by the presence of an underground river flowing into the cave: its seasonal floods can favour the entrance of these forms that are able to colonise the walls after water subside. In some cases, several authors noticed the presence of rheophilous taxa, such as Hannaea arcus (Ehrenberg) R.M. Patrick (Claus, 1962b; Lauriol et al., 1995, 2006) or species that can be considered as invasive in streams such as Didymosphenia geminata (Lyngbye) M. Schmidt in Schmidt et al. (Lauriol et al., 1995, 2006; Blanco \& Ector, 2009).

Diatoms living in ice caves can show both epicryotic and endocryotic habitus, living respectively on the ice surface or inside ice water bubbles. Mineral salt content of the ice sustains diatom communities that are able to secrete extracellular polysaccharides protecting them from freezing (Lauriol et al., 2006).

Škaloud (2009) investigated the peculiar subterranean system of ventaroles: cranny systems of massive rocks allowing permanent air circulation, resulting in the origin of summer ice holes and winter warm air exhalations. Ventaroles show a peculiar and rich algal community: concerning diatoms, the flora is composed of taxa commonly found in cave systems, also ice ones, and rivers (see Table 2 for details on composition) (Škaloud, 2009).

In Table 2 (available online at http://dx.doi. org/10.5038/1827-806X.43.3.1) we report a complete checklist of the diatom taxa found in subterranean environments and published in literature.

The analysis of these data highlighted that the most frequent and abundant species recorded in subterranean ecosystems are (in order of frequency): Hantzschia amphioxys, Diadesmis contenta, Orthoseira roeseana, Luticola nivalis, Pinnularia borealis, Diadesmis biceps Arnott ex Grunow in Van Heurck, and Luticola mutica (see Figures 1-2 as example). They are often recorded syntopically, colonizing the same portion of the walls (Germain, 1935; St. Clair \& Rushforth, 1976; Buczkó \& Rajczy, 1989; Garbacki et al., 1999; 
Buczkó, 2003; Lauriol et al., 2006; Poulíčková \& Hašler, 2007; Czerwik-Marcinkowska \& Mrozińska, 2009, 2011; Vinogradova \& Mikhailyuk, 2009). All of these species are aerophilous and may be commonly recorded in soils (Petersen, 1928; Lund, 1946; Bock, 1963; Ettl \& Gärtner, 1995; Hahn \& Neuhaus, 1997; Souffreau et al., 2010). From an ecological point of view they are generally euriecious and may proliferate in a variety of environmental conditions.

A brief synopsis on the ecology and distribution of each of these species follows.

\section{Hantzschia amphioxys (Ehrenberg) Grunow in} Cleve \& Grunow 1880

Basionym: Eunotia amphioxys Ehrenberg 1843

Hantzschia amphioxys is an aerophilous species (Germain, 1981); it is one of the most frequently recorded taxa on submerged bryophytes (Reichardt, 1985; Van de Vijver \& Beyens, 1997) and wet habitats, including soils and rock crevices (Garbacki et al., 1999; Taylor et al., 2007). This species is commonly also found in dry habitats and temporary water pools. In rivers it is often sampled in critical hydrological conditions, such as recent droughts and initial
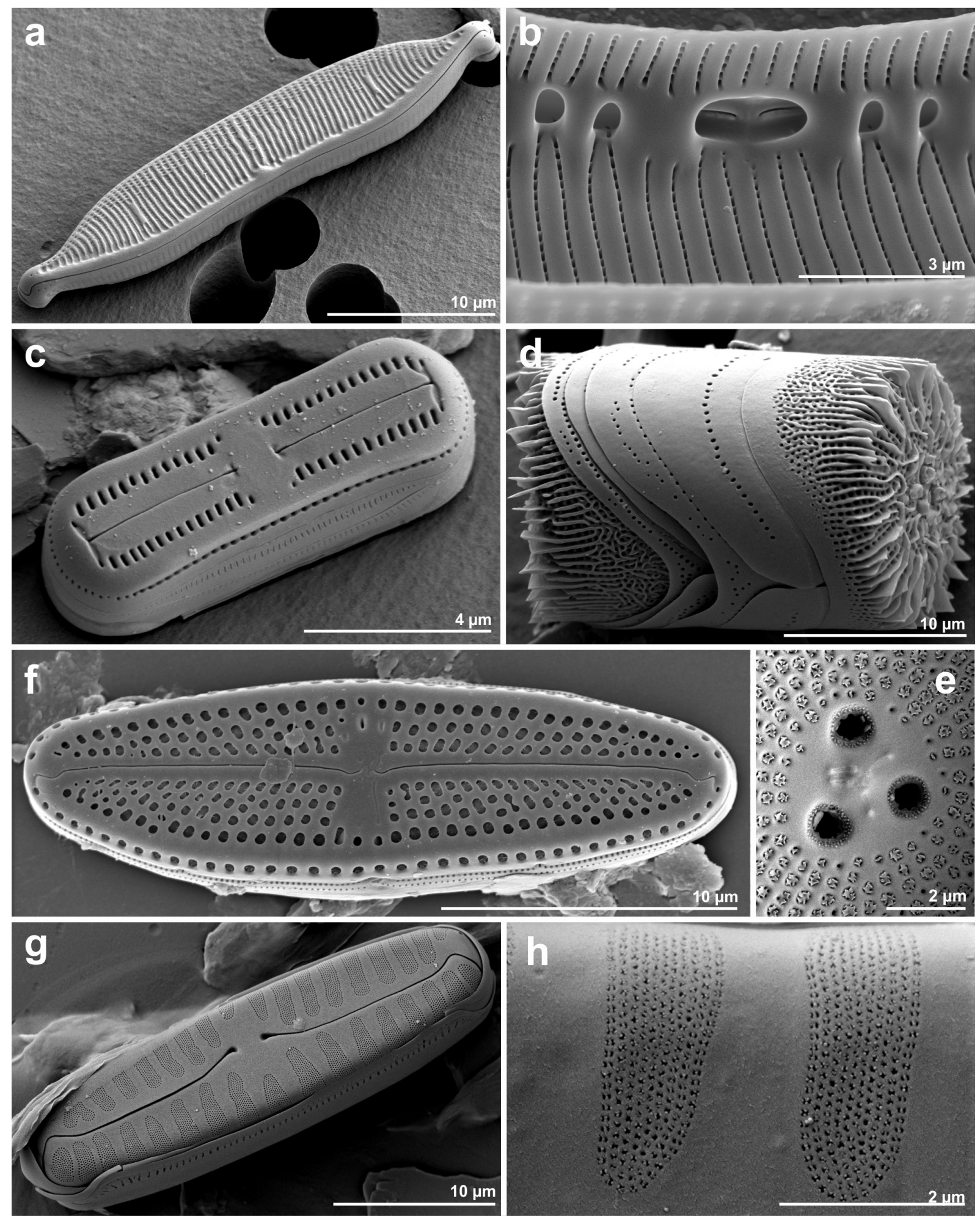

Fig. 1. SEM micrographs of common aerophytic diatoms. a-b) Hantzschia amphioxys, external view (a) and internal details of interrupted raphe and fibulae (b). c) Diadesmis contenta, external view. d-e) Orthoseira roeseana sensu lato, girdle view (d) and inner details of carinoportulae (e). f) Luticola mutica sensu lato. g-h) Pinnularia borealis, external view (g) and details of multiporoid striae (h). 
recolonization of the substrates (Pfister et al., 2009; Hofmann et al., 2011). It is considered cosmopolitan, a-mesosaprobous in freshwater habitats (Van Dam et al., 1994), occurring mainly in alkaline waters (Czerwik-Marcinkowska \& Mrozińska, 2011). The morphology is highly variable and probably consists of different lineages (Souffreau et al., 2013). Hantzschia amphioxys has been recorded in $43 \%$ of the literature data analysed for this revision, showing a worldwide distribution (Belgium, Canada, Czech Republic, France, Germany, Hungary, Italy, Luxembourg, Poland, Russia, Slovakia, Spain, Turkey, UK,
Ukraine, USA). Apart from caves H. amphioxys is also recorded in sinkholes (Hernández-Mariné et al., 2001; Buczkó, 2003) and in ice caves, where it dominates the communities collected on the iced floor and cryogenic calcite powders (Lauriol et al., 1995, 2006). The composition of the substrate does not seem to be a limiting factor for this species, that is found both in limestone and sandstone subterranean habitats (Darienko \& Hoffmann, 2006; Selvi \& Altuner, 2007).

Hantzschia amphioxys has been recorded in show caves with artificial lighting systems (St. Clair \& Rushforth, 1976), both in naturally illuminated
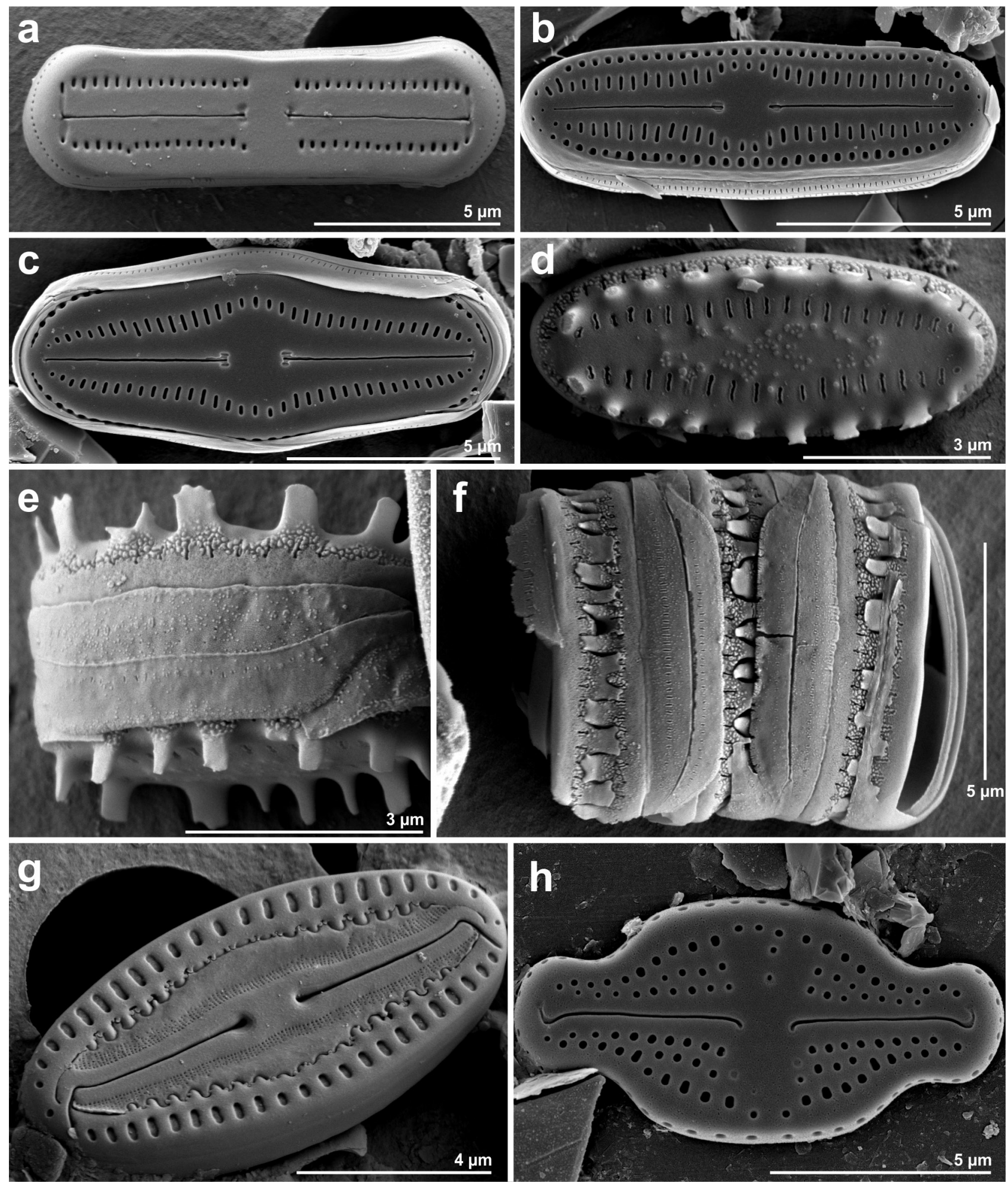

Fig. 2. SEM micrographs of common aerophytic diatoms. a) Diadesmis contenta, external view. b) Diadesmis brekkaensis, external view. c) Diadesmis perpusilla, external view. d-f) Diadesmis gallica. External valvar (d) and girdle view (e-f) of colony forming specimens. g) Fallacia insociabilis, external view. h) Luticola aff. ventricosa, external view. 
sections, near the cave opening, and artificially illuminated ones (Bahls, 1981; Smith \& Olson, 2007; Czerwik-Marcinkowska \& Mrozińska, 2011; Mazina \& Maximov, 2011). In wild caves, it has been recorded both in the liminar zone, close to the cave opening on very wet walls (Garbacki et al., 1999), but also in dim light or completely dark environments inside the caves, where the relative humidity of the air is sufficiently high (Palik, 1966; Asencio \& Aboal, 2000a, b; Hernández-Mariné et al., 2001; Buczkó \& Németh, 2009), sometimes with abundant populations (Claus, 1955). Beside wet walls, Poulíčková \& Hašler (2007) recorded $H$. amphioxys on mosses and in freshwater ecosystems inside the caves, such as lakes (Palik, 1966).

Diatoms living in subterranean ecosystems generally prefer very humid habitats and stable environmental conditions. For instance, $H$. amphioxys was abundant in subterranean habitats characterized by a wide range of temperature $\left(8-14^{\circ} \mathrm{C}\right)$ and humidity (65$100 \%$ ) among the seasons (Mazina \& Maximov, 2011). Despite this, $H$. amphioxys has also been found in non-artificially illuminated caves (La Serreta, Spain), characterized by large light intensity fluctuations (varying from 0.1 to $335 \mu \mathrm{E} \mathrm{m} \mathrm{m}^{-2} \mathrm{~s}^{-1}$ ), air humidity (ranging from 27.1 to $81.4 \%$ ) and temperature (from 9.8 to $31.5^{\circ} \mathrm{C}$ ) (Asencio \& Aboal, 2000b). This is confirmed by the presence of $H$. amphioxys as part of the cenosis found at the entrance of the Shulgan-Tash Cave (Southern Urals), exposed to daylight and to wide fluctuations of temperature and humidity through the seasons (Abdullin, 2009, 2011). Hantzschia amphioxys does not seem to be particularly sensitive to $\mathrm{pH}$, being recorded in caves whose seepage $\mathrm{pH}$ ranges from 5.6 to 8.5 (Poulíčková \& Hašler, 2007) and on sandstone substrates, characterized by a lower $\mathrm{pH}$ in comparison to limestone (Darienko \& Hoffmann, 2006).

\section{Diadesmis contenta (Grunow ex Van Heurck) D.G. Mann in Round, Crawford \& Mann 1990}

Basionym: Navicula contenta Grunow ex Van Heurck 1885

Diadesmis contenta is an aerophilous species characterized by small cell dimensions (Van Dam et al., 1994; Hofmann et al., 2011). In freshwater habitats it shows preferences for circumneutral $\mathrm{pH}$, low conductivity and nutrient content (Blanco et al., 2010). It can be considered $\beta$-mesosaprobous (Van Dam et al., 1994), belonging to high profile guild (Passy, 2007), motile and able to produce colonies (Rimet \& Bouchez, 2012). Data from this review show a world wide distribution in subterranean ecosystems, being found in $41 \%$ of the literature analysed. Apart from caves, several authors found $D$. contenta in sinkholes (Hernández-Mariné et al., 2001; Buczkó, 2003) and in ice caves, where it dominates the communities collected on the iced floor, cryogenic calcite powders and ice stalagmites (Lauriol et al., 1995, 2006). Diadesmis contenta was also recorded in ventaroles, on different substrates, both on rocks and mosses (Škaloud, 2009). Hernández-Mariné et al. (2001) found this species in non-artificially illuminated subterranean ecosystems but several authors reported its presence in illuminated subterranean systems (Skuja, 1970; Bahls, 1981; Hoffmann \& Darienko, 2005; Smith \& Olson, 2007; Mazina \& Maximov, 2011). In wild caves the species was found at dim light (Roldán et al., 2004; Taylor et al., 2007; Czerwik-Marcinkowska \& Mrozinska, 2009; Hofmann et al., 2011; Mazina \& Maximov, 2011). At very low light conditions, it occupies the upper layers of the biofilm (Hernández-Mariné et al., 2001).

Diadesmis contenta is an euriecious species recorded in very different environmental conditions. Abdullin (2009) recorded it at the entrance of the Shulgan-Tash Cave (Southern Urals), exposed to daylight and to wide fluctuations of temperature and humidity through the seasons. In Thurston Lava Tube in Hawaii, this species was recorded near the tube entrance and exit, in areas illuminated by natural light. Diadesmis contenta was found both on wet walls and bryophytes (Rushforth et al., 1984; Roldán \& Hernández-Mariné, 2009), being abundant on the lithic substrate and rare on the latter. During their research, the authors also investigated the middle portion of the lava tube (artificially illuminated by incandescent light) but the species was not recorded in these conditions (Rushforth et al., 1984). Again, in the Hawaii Islands, at the Haena wet Cave on Kaua'i, $D$. contenta was found close to the cave entrance, on a naturally illuminated wet wall, but not exposed to the direct sunlight. The internal part of the cave was probably washed over by ocean surges during the frequent hurricanes beating on the island (Main, 2003). Diadesmis contenta was also recently detected on the wall at the Kungsträdgården metro station in Stockholm, Sweden (Norbäck Ivarsson et al., 2013).

Diadesmis contenta does not show preferences in terms of substrate composition, being present both on calcite (Skuja, 1970; Hernández-Mariné et al., 2001; Selvi \& Altuner, 2007; Norbäck Ivarsson et al., 2013) and sandstone (Hoffmann \& Darienko, 2005). Following Garbacki et al. (1999), D. contenta seems to survive in different environmental conditions both in terms of light and water availability. Accordingly, Germain (1935) and Abdullin (2009, 2011) detected $D$. contenta both on poring seepages and dry surfaces inside the same subterranean habitat and CzerwikMarcinkowska \& Mrozińska (2011) found it both in high and low air humidity conditions. Despite this, air humidity and temperature shall be preferentially constant through the seasons. Diadesmis contenta was found in subterranean habitats characterized by a wide range of temperature and humidity (respectively $8-14^{\circ} \mathrm{C}$ and $65-100 \%$; Mazina \& Maximov, 2011) among the seasons. Concerning $\mathrm{pH}, D$. contenta seems to be able to colonize acid seepages as well $(\mathrm{pH}=3.7-$ 6.0) (Poulíčková \& Hašler, 2007).

\section{Orthoseira roeseana (Rabenhorst) O'Meara 1875}

Basionym: Melosira roeseana Rabenhorst 1852

Orthoseira roeseana is considered aerophilous (Krammer \& Lange-Bertalot, 1991; Houk, 2003) and xerotic (Germain, 1981). It is commonly found on wet walls, moist stones and rocks, mosses and even on the wet banks of the riparian vegetation (Patrick, 1977; Van Dam et al., 1994; Garbacki et al., 1999; 
Houk, 2003; Czerwik-Marcinkowska \& Mrozińska, 2011), in alkaline areas (Wehr \& Sheath, 2003). This species has been recorded in $30 \%$ of the literature analysed (Austria, Belgium, Canada, Czech Republic, France, Germany, Hungary, Poland, Spain, Ukraine and USA).

In caves, Orthoseira roeseana is usually found in the liminar zone, exposed to natural light (Dobàt, 1970; St Clair et al., 1981; Garbacki et al., 1999), but several authors found it on artificially illuminated walls (St. Clair \& Rushforth, 1976; St Clair et al., 1981; Roldán \& Hernández-Mariné, 2009). This is also the case of Lewis and Clark caverns (Montana, USA), where $O$. roeseana is considered as autochthonous and non accidental or brought from the external (Lauriol et al., 2006). Orthoseira roeseana does not show selective preferences in terms of air humidity, being found in very different environments (Rajczy et al., 1986), including dry surfaces (Germain, 1935). Indeed, O. roeseana seems to be adapted to really variable environments (high rate of natural ventilation, relatively low air humidity and wide range of temperature through the seasons; Roldan \& Hernández-Mariné, 2009). This is confirmed by the presence of $O$. roeseana in ventaroles where it was recorded on different substrates, both rocks and mosses (Roldán \& Hernández-Mariné, 2009; Škaloud, 2009). Orthoseira roeseana was also found on a woody surface, close to the main entrance of a small wild ice cave in Hungary, where air temperature ranges from 1 to $7.5^{\circ} \mathrm{C}(\mathrm{Kol}, 1964)$. In ice caves where it dominates the communities, $O$. roeseana was collected on the iced floor and cryogenic calcite powders (Lauriol et al., 1995, 2006). Buczkó (2003) and Roldán et al. (2004) recorded this species in sinkholes.

\section{Luticola nivalis (Ehrenberg) D.G. Mann in Round, Crawford \& Mann 1990}

Basionym: Navicula nivalis Ehrenberg 1853

Luticola nivalis is commonly found in freshwater ecosystems (lowland rivers) and is able to tolerate high conductivity (Hofmann et al., 2011) and nutrient levels (Van Dam et al., 1994; Czerwik-Marcinkowska \& Mrozińska, 2011). Luticola nivalis was cited in $23 \%$ of the analysed literature and recorded in 11 countries (Canada, Czech Republic, France, Hungary, Luxembourg, Poland, Russia, Spain, Turkey, Ukraine and USA). It has been frequently found on rock surfaces and mosses (Hofmann et al., 2011), often in association with $O$. roeseana (Germain, 1981). Nagy (1965) and Hofmann et al. (2011) considered it cryophilic. Luticola nivalis was found in touristic and artificially illuminated subterranean ecosystems (Nagy, 1965), but also in completely dark sites inside the cave (Buczkó \& Németh, 2009). In ice caves it was abundantly found on ice stalagmites (Lauriol et al., 1995, 2006) and Buczkó (2003) found it also in sinkholes. Luticola nivalis is a halophilous species, therefore, the high conductivity of the seepages on cave walls (due to the high evaporation rate) does not represent a limiting factor for its growth (Pouličková \& Hašler, 2007). Luticola nivalis was also found on dry surfaces (Germain, 1935) and does not show any preference in terms of $\mathrm{pH}$, being found in limestone (Selvi \& Altuner, 2007) and sandstone (Darienko \& Hoffmann, 2006) subterranean habitats.

\section{Pinnularia borealis Ehrenberg 1843}

Pinnularia borealis is a cosmopolitan taxon, occurring in lentic and lotic systems from lowland rivers to mountain streams; this species and all its varieties (Hofmann et al., 2011) are typically aerophilous and epiphytic (Germain, 1936; Krammer \& Lange-Bertalot, 1986; Van de Vijver \& Beyens, 1997; Garbacki et al., 1999; Taylor et al., 2007; Czerwik-Marcinkowska \& Mrozińska, 2011), often anemophilous (Krammer, 2000). It is one of the most frequently recorded taxa on submerged bryophytes (Reichardt, 1985; Van de Vijver \& Beyens, 1997). Pinnularia borealis is highly variable in terms of morphological features and probably consists of different lineages (Souffreau et al., 2013). In this review it was recorded in $22 \%$ of the analysed papers and in 12 countries (namely Belgium, Bulgaria, Canada, Czech Republic, Germany, Hungary, Luxembourg, Poland, Russia, Slovenia, Turkey and USA).

Rajczy et al. (1986) and Garbacki et al. (1999) found this species in wild caves, close to the main entrance on very wet walls, but Hoffmann \& Darienko (2005) also recorded it in a show cave. Pinnularia borealis was also recorded in ice caves, where it dominates the communities collected on the iced floor and cryogenic calcite powders (Lauriol et al., 1995, 2006), in calcareous subterranean environments (Selvi $\&$ Altuner, 2007), but also on sandstone (Darienko \& Hoffmann, 2006). It is also present in sinkholes (Buczkó, 2003). It does not show any particular environmental requirements in terms of humidity and substrate: it is possible to find it both in wet and dry air contitions (Czerwik-Marcinkowska \& Mrozińska, 2011), both on temporarily wet rocks (Reichardt, 1985) and mosses (Pouličková \& Hašler, 2007 citing Reichardt, 1985).

\section{Diadesmis biceps Arnott ex Grunow in Van Heurck 1880}

Van Dam et al. (1994) classified Diadesmis biceps as $\beta$-mesosaprobous and alcaliphilous, with a preference for low conductivities. In our review, it was found in $19 \%$ of the analysed papers, corresponding to 9 countries (Belgium, Canada, Hawaii, Hungary, Italy, Luxembourg, Slovenia, Ukraine and USA).

This species has been frequently recorded on wet cave walls or mosses in springs (Garbacki et al., 1999). Diadesmis biceps was found in illuminated areas of show caves (Skuja, 1970; Mulec et al., 2008), but also in the liminar zone of a wild cave (Rajczy et al., 1986; Mulec \& Kosi, 2008; Mulec et al., 2008). Moreover Dayner \& Johansen (1991) found it in the laminar zone of a show cave. Diadesmis biceps was also found in Thurston Lava Tube in Hawaii (Rushforth et al., 1984), near the main entrance and exit, in naturally illuminated areas. Diadesmis biceps was found both on wet walls and bryophytes (see also Dayner \& Johansen, 1991). During this research, Rushforth et al. (1984) investigated also the middle 
portion of the lava tube (artificially illuminated by incandescent light) but the species was not recorded in these conditions. Despite this, artificial light seems not to be a limiting factor for $D$. biceps proliferation: at the Oregon Caves National Monument (Oregon) it was abundantly recorded in both naturally and artificially illuminated sections of the caves (St Clair et al., 1981). Diadesmis biceps is very abundant and also spreads in the Timpanogos Cave National Monument (Utah), both close to the main entrance and along the artificially illuminated path (St. Clair \& Rushforth, 1976). Diadesmis biceps was also recorded in ice caves, where it shows a preference for ice stalagmites (Lauriol et al., 2006). Diadesmis biceps does not show selective preferences in terms of air humidity, being found in very different environments (Rajczy et al., 1986), even dry ones (Dayner \& Johansen, 1991). It does not show preferences in terms of substrate and it was found in caves composed of calcite, dolomitic limestone (Dayner \& Johansen, 1991), but also on sandstone (Darienko \& Hoffmann, 2006); considering this, it seems that $D$. biceps does not present particular preferences in terms of $\mathrm{pH}$.

\section{Luticola mutica (Kützing) D.G. Mann in Round, Crawford \& Mann 1990}

Basionym: Navicula mutica Kützing 1844

Luticola mutica is one of the most frequently recorded taxa on submerged bryophytes (Reichardt, 1985; Van de Vijver \& Beyens, 1997); it is resistant to moderatehigh conductivity levels (Pouličková \& Hašler, 2007). In freshwater ecosystems, given its tolerance to high conductivity and nutrient levels, it is commonly found in lowland rivers (Van Dam et al., 1994; CzerwikMarcinkowska \& Mrozińska, 2011). It was recorded in $14 \%$ of the literature analysed in this review and in 9 countries (Canada, Czech Republic, France, Poland, Slovenia, Spain, Turkey, Ukraine and USA).

It has been detected in touristic caves both on naturally illuminated walls close to the entrance and along the pathways in correspondence to artificial lights (St. Clair \& Rushforth, 1976; Bahls, 1981). Mulec et al. (2008) report a record of the species along $24 / 24$ h artificially illuminated pathways, in a lead and zinc mine. A few individuals were collected in a wild caves, in the dark zone (Claus, 1955). Luticola mutica can be detected both on wet rocks and mosses (Reichardt, 1985; Pouličková \& Hašler, 2007) and in ice caves (Lauriol et al., 2006). Luticola mutica is a halophilous species; as a consequence, the high conductivity of the seepages on cave walls (due to the high evaporation rate) does not represent a limiting factor for its growth (Pouličková \& Hašler, 2007). Luticola mutica was also recorded in ventaroles, on rocks and mosses (Škaloud, 2009).

\section{NEW AND RARE SPECIES}

Due to the peculiarity of the subterranean environment, the record of rare or new species is relatively common. This is the case of Diprora haenaensis Main described as new genus and new species in 2003, and detected for the first time in
Haena Wet Cave (North tip of Kaua'i, Hawaiian Islands). This new species presents highly silicified valves and a new structure ("prows"), pronounced pervalvar extensions of the mantle in correspondence of the poles (Main, 2003). Nowadays, D. haenaensis is the only described species belonging to the genus Diprora. Main (2003) recorded this species in the type locality, on a wet wall and ceiling not exposed to direct sunlight, inside the Haena Wet Cave. The species was dominant in the sample and it was associated with other aerophilous taxa typical of the Hawaiian Islands. Indeed, in this case, the communities colonising the cave wall in both sampling seasons, did not share many species with the typical assemblages from subterranean environments in Europe and America. Only Diadesmis contenta was recorded (not abundantly) in the Hawaiian community, while it is considered one of the key taxa of diatom cave flora in Europe. Diprora haenaensis was recently collected in Maniniholo Dry Cave (Kaua'i, Hawaiian Islands). Molecular analyses, based on nuclear (SSU rDNA) and chloroplast ( $r b c \mathrm{~L}, \mathrm{pbsC}$ ) genes, conducted on this population showed the close relation of this taxon with raphid diatoms. Despite this, no raphe system nor vestigial raphe has been detected in the whole sample (about 100,000 valves observed) (Kociolek et al., 2013).

Recently, Taylor \& Lange-Bertalot (2013) described Cholnokyella aerophila as new species and genus in South Africa. The species was recorded from a sandstone overhang at Bushman's Cave (South Africa) and was associated with Nostoc spp. colonies. The peculiarities of the species are the cruciform outline of the valve (often asymmetrical), the structure and pattern of the areolae and a single chloroplast. The species usually forms short colonies. Cholnokyella aerophila is probably not strictly aerophilic, being also found in a river rising from a cave, $40 \mathrm{~km}$ far from the type locality. It seems to prefer alkaline seep waters and its growth seems not limited by light and humidity. Most of the ecological preferences of the species are, however, still unknown. The study of the Thurston Lava Tube in the Hawaii Volcanoes National Park provided the discovery of several new species, i.e. Navicula hawaiiensis J.R. Johansen in Rushforth, Kaczmarska \& Johansen and Navicula thurstonensis Kaczmarska in Rushforth, Kaczmarska \& Johansen (Rushforth et al., 1984). The first was recorded close to the lava tube entrance, on a wet wall at $1250 \mathrm{~m}$ a.s.1.. The latter, collected both on naturally and artificially illuminated sections, has been recently transferred to the genus Nupela as $N$. thurstonensis (Kaczmarska) Kulikovskiy et al. due to its raphe structure, long in both valves with proximal raphe ends characterized by very small punctiform central pores (Kulikovskiy et al., 2010). Diatom flora in lava tubes is quite constant over the years and seasons (Rushforth et al., 1984) and shows several affinities with the aerophilous and moss-dwelling communities found in Europe. Navicula hawaiiensis and $N$. thurstonensis are known from the only type locality. In 2013, two new species were described from a small pool located at the bottom of a lava tube in Île Amsterdam (TAAF, Southern 
Indian Ocean; Van de Vijver \& Cox, 2013). These new species, Sellaphora barae Van de Vijver \& E.J. Cox and Mayamaea cavernicola Van de Vijver \& E.J. Cox, were described as new for science, while a third species Chamaepinnularia aerophila Van de Vijver $\&$ Beyens was previously described from the nearby Crozet archipelago (Van de Vijver et al., 2002a) and as a new record for Île Amsterdam (Van de Vijver \& Cox, 2013). Before this last publication, the same authors observed $M$. cavernicola also in small caves at the Île de la Possession (Van de Vijver et al., 2002a). The distributional range of these species is, nowadays, limited to the Southern Indian Ocean.

Luticola spinifera (W. Bock) Denys \& W.H. De Smet was described as Navicula spinifera W. Bock in 1970 by Bock and rarely recorded afterwards (only in San Gimignano, Italy and in Bodiam Castle, Sussex). This particular species shares common features both with Luticola (stretched plastid, presence of stigma, longitudinal canal and dentate valvocopula) and Diadesmis (elongated poroids, linking spines, absence of notches). The long spines, visible even under the light microscope, are irregularly disposed but always present and allow the formation of short chains (up to 6 individuals) that strongly adhere to soil substratum. The formation of colonies can be considered an adaptive strategy to extreme stress conditions, such as water loss through valvar surface. Several populations were recorded in Turkey and seemed to prefer calcareous substrates and mosses for colonization and, due to the reduced competitiveness with the other soil species, they tend to colonize sheltered and inclined substrates (Denys \& De Smet, 1996). According to Levkov et al. (2013) Luticola spinifera is a widely distributed species in aerial habitats.

In 1966, VanLandingham collected and described three new Cymbella species from the bottom mud of small ponds in the Mammoth Cave (USA): Cymbella clausii VanLandingham, Cymbella gerloffii VanLandingham and Cymbella hohnii VanLandingham. Cymbella clausii presents small valves with very broad axial area, acute poles and no stigma. Cymbella gerloffii shows narrow valves and round apices; the raphe slit is deflected toward the ventral side of the valve and lies down in a longitudinal area gradually enlarged in the middle. Cymbella hohnii presents similar features to Cymbella cymbiformis C. Agardh but shows a broader central area; it has been transferred in the genus Encyonema by Krammer in 1997. Beside Cymbella species, VanLandingham (1967) described a new Gomphonema, named Gomphonema hotchkissii VanLandingham. This species, collected in the Mammoth Cave (USA), shows subcapitate apices and a broad elliptical axial area. These Cymbella and Gomphonema species, described by VanLandingham from Mammoth Cave, are so far only known from the type locality.

In 1971, Carter described five new species from Devil's Hole cave in Scotland, namely: Caloneis borealis J.R. Carter, Cymbella diavola J.R. Carter, abundant in such cave and morphologically variable, closely related to Cymbopleura angustata (W. Smith) Krammer, Navicula variolineata J.R. Carter, not frequent in the cave, closely related to Cavinula lacustris (Gregory) D.G. Mann \& Stickle in Round, Crawford \& Mann, Navicula vula J.R. Carter, similar to Kobayasiella jaagii (F. Meister) Lange-Bertalot, but with different central area and terminal fissures, and Nitzschia disputata J.R. Carter, belonging to the section Grunowiae. After 1971, C. borealis was collected in salt marsh deposits recovered from a field site near Sisimiut (West Greenland; Long et al., 2010) and on dried macrophytes preserved in an herbarium and collected from the artificial lake Kraenepoe (Belgium), between 1853 and 1983 (Denys, 2009). Navicula vula was also recorded in sediment samples from the bottom layer and fine detrital gyttja collected from a tarn at Røyrtjønn (Lista peninsula; Norway - Prøsch-Danielsen, 1997); again it was recorded in December 2004 in phytoplankton samples collected from the East China Sea, in proximity of the Jeju Island (Affan \& Lee, 2004). These records lead us to conclude that $N$. vula species is not strictly aerophilous and can inhabit both fresh and brackish waters. Moreover, Nitzschia disputata was also recorded in several surface ecosystems: in particular, it was collected in epilithic samples from small lowland rivers located in the Northern-Central region of Portugal, showing a preference for low conductivity, acid waters with low organic matter concentrations (Almeida \& Gil, 2001). Again, collected in lowland rivers (small tributaries of the Douro River) affected by organic pollution in the North-West Portugal, where it shows a seasonal preferences for cold months (Elias et al., 2012). Nitzschia disputata was collected also in rivers in Southern Finland, showing preferences for oligotrophic stretches (Soininen \& Könönen, 2004). It was also detected in an acid small rainwater pool close to an abandoned iron mine at Skelton (England; Denys \& Carter, 1989), and it was part of the periphytic community collected in a near-pristine lake in the UK (Kelly et al., 2009).

In 2003, Buczkó collected a dense population of the rare Diadesmis brekkaensoides (W. Bock) Moser, Lange-Bertalot \& Metzeltin in the Kiskőhát shaft, a protected sinkhole located in the Bükk National Park (Hungary). Apart from the type locality, Diadesmis brekkaensoides was illustrated by Reichardt (2004, p. 429, pl. 1: 24-28, pl. 7: 4-6) from a spring in Graz (Bergland), Austria, in Hochlantsch mountains. The location, called "Schüsserlbrunn" is a recess in a wall of Devonian limestone where dripping water has formed some small hollows. One sample was collected from a depression in the outer area of the recess which was only slightly shaded.

\section{MORPHOLOGICAL VARIATIONS IN DIATOMS OF SUBTERRANEAN HABITATS}

Aquatic species may show some morphological modifications when growing on wet surfaces aerophilous taxa may change their morphology when growing in freshwater. Indeed, it has been demonstrated that the genus Diadesmis is highly polymorphic (Poulíčková \& Hašler, 2007): D. gallica, in particular, can be subject to phenotypic 
polymorphism; it is mainly a terrestrial or subaerial diatom. Diadesmis gallica can present two kinds of morphs: the first showing raphe system on both valves and lacking marginal spines; the second forming colonies through linking spines located in the valve margins and lacking a raphe system (Granetti, 1978; Albertano et al., 1995; Cox, 2006). Probably, this phenomenon could be related to adaptations to different conditions: aerophilous specimens, already adapted to live to moist surfaces, can easily survive as single cells anchored by means of the mucilage secretion through raphe. On the other hand, floating in liquids such as standing waters, can be faced by the formation of colonies for which the production of the spine is necessary (Cox, 2006). A new variety of D. gallica, at that time described as Navicula gallica var. montana Bahls (Bahls, 1981), showed the same kind of polymorphism. During the analysis of the diatom flora in Lewis and Clark caves, Bahls found particular specimens differing from $D$. gallica by length and outline of the valves (longer and more linear in Navicula gallica var. montana). It was observed that part of the individuals belonging to the new population lacked the raphe system (Bahls, 1981). Finally, the raphe system in $D$. gallica found in Roman Catacombs was reduced or completely absent in most of the specimens; on the contrary, some individuals lacking marginal spines presented a very short raphe (ca. 2 um long) probably denoting an adaptation to solitary cells life form on cave walls (Albertano et al., 1995). It has been frequently observed that $D$. gallica produces also teratological forms involving different parts of the cell (outline, raphe system, central and axial areas, pores, spines); this is probably induced by the highly variable environmental conditions, mainly in terms of humidity and light, in which the species usually occurs (Granetti, 1978).

Diatoms colonising wet walls are adapted to unstable environments, not always completely wet. To face desiccation, some populations (for example belonging to the genera Chamaepinnularia, Diadesmis, Eunotia or Nupela) show particular siliceous lamina occluding the areolae; moreover, the number of areolae can also be lowered (Lowe et al., 2007). Reduced external openings are also typical for species of the genera Decussata, Luticola, Microcostatus and Nitzschia when colonising wet walls (Lowe et al., 2007). To prevent desiccation during reproduction, Luticola dismutica (Hustedt) D.G. Mann in Round, Crawford \& Mann produces a thin protective layer of mucilage around gametes and zygotes (Poulíčková, 2008).

In 1971, Carter observed that diatom populations, collected from Devil's hole cave in Scotland, presented very small dimensions and finer silica structure, probably due to adaptation to subterranean habitats. In particular, Achnanthes perfida J.R. Carter, Brachysira vitrea (Grunow) R. Ross in Hartley, Craticula halophila (Grunow ex Van Heurck) D.G. Mann in Round, Crawford \& Mann, Pinnularia intermedia (Lagerstedt) Cleve and Pinnularia major Brébisson in Rabenhorst presented smaller valves, while Frustulia creuzburgensis (Krasske) Hustedt, Nitzschia perminuta (Grunow in Van Heurck) Peragallo and Navicula digitoradiata (W. Gregory) Ralfs in Pritchard showed a finer striation than in the original description (Carter, 1971).

Morphological alterations in the shape of valves and horse-shoe area (or "sinus") were found in Planothidium lanceolatum (Brébisson ex Kützing) Lange-Bertalot (cited as Achnanthes lanceolata (Brébisson ex Kützing) Grunow in Cleve \& Grunow) collected from lava tubes (Rushforth et al., 1984). The same authors found some atypical morphological characters in the populations collected in this site, if compared to the classical species descriptions. This is the case of Rossithidium pusillum (Grunow) Round \& Bukhtiyarova in Bukhtiyarova (cited as Achnanthes linearis var. pusilla Grunow in Cleve \& Grunow), Encyonema minutum (Hilse in Rabenhorst) D.G. Mann in Round, Crawford \& Mann (as Cymbella minuta), Eunotia praerupta Ehrenberg, Eunotia tenella (Grunow in Van Heurck) Hustedt in Schmidt et al., Adlafia bryophila (J.B. Petersen) Gerd Moser, LangeBertalot \& Metzeltin (as Navicula bryophila), and Pinnularia leptosoma (Grunow in Van Heurck) Cleve.

Exposure to low light can also result in particular physiological strategies: indeed, autotrophs in subterranean environments may show a certain degree of heterotrophy (Palik, 1960; Giordano et al., 2000). Changes in cell ultrastructure have been studied in cyanobacteria and chlorophytes (Albertano et al., 1991a) but not yet on diatoms.

It has been observed that morphological and physiological adaptations disappear once the populations are cultured in the laboratory, assuming their normal aspect and reactivating physiological processes (Schagerl, 1991).

It is well known that diatom species are subject to morphological plasticity, developing features that allow facing and surviving in particular environmental conditions. By analysing literature data, we compare the morphometric features of the most common species found in subterranean ecosystem with those reported in literature for the same species when found in freshwater ecosystems (Table 3).

When comparing morphometric data found in literature, no statistically significant differences were found between surface water and subterranean environments. Mann-Whitney test was performed on min and max values of valve length and width, and on minimal and maximal values of striae density (PCORD vers. 6.0; McCune \& Mefford, 2011). As expected, freshwater diatoms showed a wider range in length and width measures. In terms of mean length, Hantzschia amphioxys and Pinnularia borealis valves seem to be longer in subterranean ecosystems than in freshwater ones, as well as in Orthoseira roeseana diameter; on the contrary, Luticola mutica shows smaller cells in caves. Moreover, as shown in Table 3, Luticola nivalis and $L$. mutica found in subterranean habitats show on average a lower density of striae in respect to those found in rivers. On the contrary, striation in $O$. roeseana seems denser in subterranean ecosystems than in freshwater habitats. 
Subterranean diatom flora

Table 3. Morphometric data analysis: comparing information concerning structural features of taxa coming from freshwater environments and from subterranean ecosystems. Taxa are shown in the first column in order of frequency based on literature results.

\begin{tabular}{|c|c|c|c|c|c|c|c|}
\hline & & $\begin{array}{c}\text { Diameter } \\
\text { (range; } \mu \mathrm{m})\end{array}$ & $\begin{array}{c}\text { Length } \\
\text { (range; } \mu \mathrm{m})\end{array}$ & $\begin{array}{c}\text { Width } \\
\text { (range; } \mu \mathrm{m})\end{array}$ & $\begin{array}{l}\text { Number } \\
\text { of fibulae } \\
\text { in } 10 \mu \mathrm{m}\end{array}$ & $\begin{array}{l}\text { Number } \\
\text { of striae } \\
\text { in } 10 \mu \mathrm{m}\end{array}$ & References \\
\hline \multirow{14}{*}{$\begin{array}{l}\text { Hantzschia amphioxys (Ehrenberg) } \\
\text { Grunow in Cleve \& Grunow }\end{array}$} & \multirow{7}{*}{ from diatom floras } & & $20-100$ & $5-7$ & $5-8$ & $13-20$ & Germain, 1981 \\
\hline & & & $20-210(300)$ & $5-15(25)$ & 4-11 & $11-28$ & Krammer \& Lange-Bertalot, 1988 \\
\hline & & & $15-50$ & $5-7$ & - & $20-29$ & Lange-Bertalot, 1993 \\
\hline & & & $20-210(300)$ & $5-15(25)$ & 4-11 & $11-28$ & Taylor et al., 2007 \\
\hline & & & $35-41$ & $5-7$ & $8-10$ & $21-24$ & Lavoie et al., 2008 \\
\hline & & & $24-33.3$ & 5.3 & - & - & Kulikovskiy et al., 2010 \\
\hline & & & $15-50$ & $5-7$ & - & $20-29$ & Hofmann et al., 2011 \\
\hline & \multirow{7}{*}{ from cave literature } & & $36-43$ & $9-10$ & - & 14 & Palik, 1966 \\
\hline & & & $33-48$ & $6-7$ & $6-7$ & $20-21$ & St. Clair \& Rushforth, 1976 \\
\hline & & & $55-64$ & $6-7$ & 7-9 & - & St. Clair et al., 1981 \\
\hline & & & $45-53$ & $6.5-6.7$ & $6-7$ & $20-22$ & Garbacki et al., 1999 \\
\hline & & & 23-51 & $5.4-8.4$ & $5-8$ & $13-20$ & Asencio \& Aboal, 2000b \\
\hline & & & $43-70$ & 6-9 & 4-9 & $14-18$ & Pouličková \& Hašler, 2007 \\
\hline & & & $15.1-35.2$ & $4.1-7.1$ & - & - & Czerwik-Marcinkowska \& Mrozińska, 2011 \\
\hline \multirow{11}{*}{$\begin{array}{c}\text { Diadesmis contenta } \\
\text { (Grunow ex Van Heurck) } \\
\text { D.G. Mann in Round, Crawford \& Mann }\end{array}$} & \multirow{6}{*}{ from diatom floras } & & 7-15 & $2-3$ & - & $32-36$ & Germain, 1981 \\
\hline & & & $4-30$ & $2-6$ & - & $25-40$ & Krammer \& Lange-Bertalot, 1986 \\
\hline & & & $4-30$ & 2-6 & - & $25-40$ & Taylor et al., 2007 \\
\hline & & & $10-11$ & 3 & - & - & Lavoie et al., 2008 \\
\hline & & & $4-30$ & $2-6$ & - & $25-40$ & Blanco et al., 2010 \\
\hline & & & $4-10$ & $2-6$ & - & $40 / 10$ & Hofmann et al., 2011 \\
\hline & \multirow{5}{*}{ from cave literature } & & $12-13$ & 3-3.5 & - & 36 & Rushforth et al., 1984 \\
\hline & & & 12 & 4 & - & & Schagerl, 1991 \\
\hline & & & 8-12(14) & $2.8-3.3$ & - & 36 & Garbacki et al., 1999 \\
\hline & & & $6-13$ & $2-4$ & - & 40 & Pouličková \& Hašler, 2007 \\
\hline & & & $6.8-8.1$ & 2.4 & - & 26 & Czerwik-Marcinkowska \& Mrozińska, 2011 \\
\hline \multirow{8}{*}{$\begin{array}{l}\text { Orthoseira roeseana } \\
\text { (Rabenhorst) O'Meara }\end{array}$} & \multirow{2}{*}{ from diatom floras } & $8-10$ & & & - & 8-9 & Germain, 1981 \\
\hline & & $8-70$ & & & - & - & Krammer \& Lange-Bertalot, 1991 \\
\hline & \multirow{6}{*}{ from cave literature } & $15-31$ & & & - & 10 & St. Clair \& Rushforth, 1976 \\
\hline & & $19-33$ & & & - & $7-10$ & St. Clair et al., 1981 \\
\hline & & up to 40 & & & - & - & Schagerl, 1991 \\
\hline & & $12-30$ & & & - & 7-8 & Garbacki et al., 1999 \\
\hline & & $8.5-34.2$ & & & - & $6.4-13.4$ & Pouličková \& Hašler, 2007 \\
\hline & & $8-70$ & & & - & - & Czerwik-Marcinkowska \& Mrozińska, 2011 \\
\hline \multirow{9}{*}{$\begin{array}{l}\text { Pinnularia borealis } \\
\text { Ehrenberg }\end{array}$} & \multirow{7}{*}{ from diatom floras } & & $30-70$ & 7-15 & - & $5-7$ & Germain, 1981 \\
\hline & & & $24-110$ & $5-18$ & - & $4-6$ & Krammer \& Lange-Bertalot, 1986 \\
\hline & & & $24-42$ & $8.5-10$ & - & $5-6$ & Krammer, 2000 \\
\hline & & & $24-42$ & $8.5-10$ & - & $5-6$ & Taylor et al., 2007 \\
\hline & & & $31-41$ & 7 & - & $4-5$ & Lavoie et al., 2008 \\
\hline & & & $26-48.7$ & $6.7-10$ & - & $5-6$ & Kulikovskiy et al., 2010 \\
\hline & & & $24-42$ & $8.5-10$ & - & $5-6$ & Hofmann et al., 2011 \\
\hline & \multirow{5}{*}{ from diatom floras } & & $34-50$ & $9-12$ & - & $5-6$ & Garbacki et al., 1999 \\
\hline & & & $(24) 30-60(110)$ & $5-18$ & - & - & Czerwik-Marcinkowska \& Mrozińska, 2011 \\
\hline \multirow{5}{*}{$\begin{array}{c}\text { Luticola nivalis } \\
\text { (Ehrenberg) } \\
\text { D.G. Mann in Round, Crawford \& Mann }\end{array}$} & & & $15-35$ & $6-10$ & - & $17-18$ & Germain, 1981 \\
\hline & & & $12-42$ & $5.5-13$ & - & $17-20(24)$ & Krammer \& Lange-Bertalot, 1986 \\
\hline & & & 17 & 6 & - & 21 & Lavoie et al., 2008 \\
\hline & \multirow{2}{*}{ from cave literature } & & $11-24$ & 6-9 & - & $14-20 / 10$ & Pouličková \& Hašler, 2007 \\
\hline & & & $12-42$ & $5.5-13$ & - & $17-20(24)$ & Czerwik-Marcinkowska \& Mrozińska, 2011 \\
\hline \multirow{6}{*}{$\begin{array}{l}\text { Diadesmis biceps } \\
\text { Arnott ex Grunow in Van Heurck }\end{array}$} & & & $7-15$ & $2-3$ & & 36 & Hustedt, 1930 \\
\hline & from diatom floras & & $7-15$ & $2-3$ & & $32-36$ & Patrick, 1966 \\
\hline & & & $7-15$ & $2-3$ & & $32-36$ & Germain, 1981 \\
\hline & & & $14-15$ & 3-4 & - & $30-35 / 10$ & St. Clair \& Rushforth, 1976 \\
\hline & from cave literature & & $10-16$ & 3-4 & - & $33-36 / 10$ & St. Clair et al., 1981 \\
\hline & & & $8-12$ & $2.5-3$ & - & 36 & Rushforth et al., 1984 \\
\hline & & & $10-30$ & 6-9 & - & $13-18$ & Germain, 1981 \\
\hline & & & $6-30(40)$ & $4-9(12)$ & - & $14-20(25)$ & Krammer \& Lange-Bertalot, 1986 \\
\hline & trominationitionas & & $6-30(40)$ & $4-9(12)$ & - & $14-20(25)$ & Taylor et al., 2007 \\
\hline (Kützing) D.G. Mann in Round, & & & $6-30$ & 4-9 & - & $14-20$ & Hofmann et al., 2011 \\
\hline & & & $11-13$ & 5 & - & $16-18$ & St. Clair \& Rushforth, 1976 \\
\hline & from cave literature & & 13-19 & $6-7$ & - & $18-22 / 10$ & Pouličková \& Hašler, 2007 \\
\hline & & & $6-30(40)$ & $4-9(12)$ & - & $14-20(25)$ & Czerwik-Marcinkowska \& Mrozińska, 2011 \\
\hline
\end{tabular}


CONCLUDING REMARKS

The literature analysed refers to subterranean habitats (mostly caves) distributed in 27 different countries mainly in Europe and North America (Table 1). More than 230 papers were analysed. Within them, more than 190 studies concern the algal flora inhabiting subterranean systems, and in particular, 82 specifically refer to diatoms providing a list of recorded species. Literature data cover a temporal range of 113 years, from 1900 to 2013 (Figure 3) and provided information concerning the diatom flora colonising mainly wet walls in caves, including touristic ones. The interest of the scientific community in this subject has grown in the last decades worldwide, especially in relation to the impact of biofilm in show caves.

\section{Cave diatoms}

From this review, a total of 363 diatom taxa, belonging to 82 genera, were observed in different subterranean systems. In particular, Navicula sensu lato and Nitzschia count the highest number of species (respectively 40 and 26). The most widespread and abundant species were Hantzschia amphioxys, Diadesmis contenta, Orthoseira roeseana, Luticola nivalis, Pinnularia borealis, Diadesmis biceps, and Luticola mutica. Up to the last two decades, species concept in diatom taxonomy assumed wide boundaries leading to a broad concept. Indeed, a full understanding of the underlying causes of morphological variation patterns and speciation was generally missing and most of phenotypic variability was purely considered as environmental adaptation. Moreover, the only diatom floras available until then, referred to European freshwater diatoms. The use of these floras for the identification of diatom species in non-European freshwater ecosystems (for example Antarctica) or for the analyses of soil and aerophilous communities has to be considered as "force fitting" taxonomical practice. The arising consequences fall back into the study of diatom ecology, biogeography and lead to under-estimation of their diversity (Vanormelingen et al., 2008). Afterwards, with the increase of molecular techniques, fine and discontinuous morphological features started to

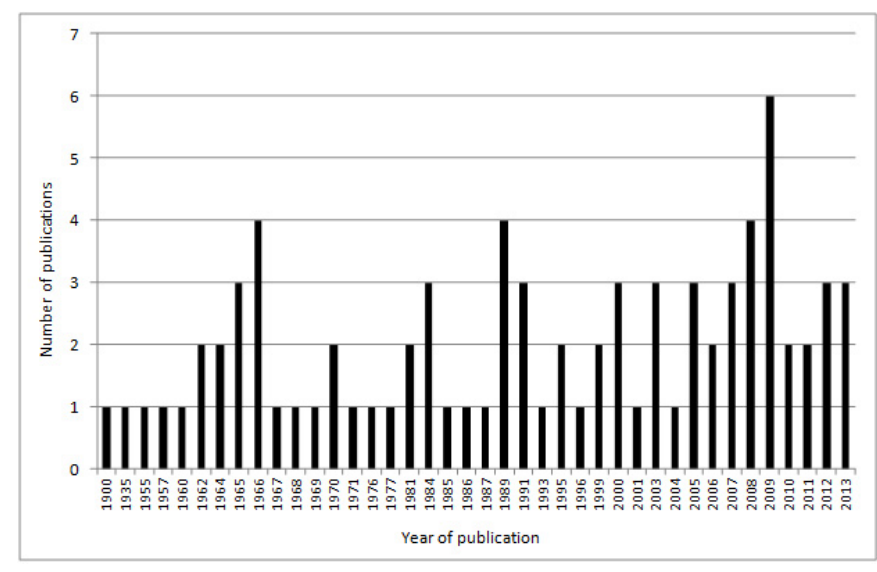

Fig. 3. Number of publications concerning diatom flora in subterranean ecosystems from 1900 to 2013. assume an important taxonomic significance. In this context, it appears clear that peculiar environments, such as subterranean ecosystems, lack more than others of specific taxonomic studies and related floras. Therefore, in this context, aerophilous species such as those belonging to the genera Diadesmis, Hantzschia and Luticola are the most involved in "force fitting" phenomena, being less studied than freshwater ones. Especially for the genus Diadesmis (Lange-Bertalot \& Werum, 2001; Le Cohu \& Van de Vijver, 2002; Van de Vijver et al., 2002b; Buczkó, 2003; Kopalová et al., 2009; Lowe et al., 2014), but also for the genera Achnanthes (Tofilovska et al., 2014) and Luticola (Kopalová et al., 2011; Levkov et al., 2013), it is important to consider that modern techniques for the morphological analyses, such as SEM, were not available and spread during the first half of the $20^{\text {th }}$ century. Fine structures in very small specimens, nowadays considered as systematic character for the determination of diatoms at species level, have not been observed during most of the researches included in this review. For instance, Luticola mutica is regularly cited in the world, also frequently in subterranean habitats; nevertheless according to Levkov et al. (2013), it is a brackish water species, occurring as epiphyte on different macrophytes in several estuaries in Europe. For these authors many of the records of Navicula mutica from freshwater habitats are related to other species similar to L. mutica (like L. frequentissima Levkov, Metzeltin \& Pavlov, L. imbricata (W. Bock) Levkov, Metzeltin \& Pavlov, L. pseudoimbricata Levkov, Metzeltin \& Pavlov, etc). For instance, the valves depicted in Krammer \& Lange-Bertalot (1986, figs 61: 1-7, as Navicula mutica Kützing var. mutica) belong to L. frequentissima. Another recent deep investigation of the species of the genus Achnanthes, including the analysis of the type material of A. coarctata, allowed Tofilovska et al. (2014) to discover and describe two new Achnanthes species in the cave Peshti, Mountain Jakupica, Macedonia. In addition, revising the Diadesmis and Paradesmis species concept, Lowe et al. (2014) proposed the creation of a new genus, based on the description of a new species, the generitype Humidophila undulata Lowe et al., found at the type locality (subaerial collection from wet wall, Nuuanu Pali Lookout, Oahu) and on drip walls and caves on the islands of Oahu, Maui and Hawai'i. Several of the species belonging actually to Diademis, as Diadesmis aerophila (Krasske) D.G. Mann or D. contenta, have been transferred to this new genus Humidophila (Lowe et al., 2014).

According to the literature investigated, diatom diversity in subterranean habitats is, in general, relatively low. Despite this, some literature data report a high number of taxa collected from caves. For example, Lauriol et al. (2006) highlighted an important number of diatom taxa in samples collected from ice caves: about 92 taxa (mainly aerophilous and allochthonous) were identified from ice cave formations in Northern Yukon Territory (Canada). Carter (1971) also recorded more than 90 taxa from the Devil's Hole Cave in Scotland. 


\section{Cave management}

Unfortunately, caves impacted by severe disturbances, including tourism and artificial illumination, have never been completely restored to their former ecological state (Elliot, 2006). Indeed, the regenerative capacity of subterranean ecosystems is very low or even null (Watson et al., 1997). Principally, every visitor entering a cave, from the professional speleologist to tourists, has the potential to exert a negative impact on the cave ecosystem. Any entry results in a cumulative and irreversible impact (Watson et al., 1997). It goes without saying, however, that for some regions of the world, caves serve as the only viable commodity and tourism is a major source of revenue (Lee et al., 2012). For example, in the Mammoth Cave region, USA, over US\$400 million were brought to the area by tourists in 2009, up from an estimate of US\$52 million in 1993 (Stynes, 1999). The socio-economic importance of karst systems is not limited to the touristic context, but also to water supplies, irrigation, hydro-electric energy and fisheries. Cave management guidelines are needed for a sustainable use of karsts resources (Watson et al., 1997).

The development of lampenflora and its consequences such as biocorrosion could be limited by physical, chemical and biological strategies. The reduction of the illumination period, the use of photosynthetically non-active wavelengths (Aley, 2004) with yellow (Smith \& Olson, 2007) or green emissions (Hoffmann, 2002; Roldán, 2008), should be considered as preventive devices; white, red and blue emissions should be avoided and, as a consequence, incandescent lighting (Imprescia, 1983; Albertano et al., 1991b). For instance, Cigna (2011) highlighted that in Mammoth Cave (USA), the new light system consisting of 49 lux and yellow light LED prevents the development of lampenflora up to 1.5 year after its removal. The increase of the distance between speleothems and light (at least $1 \mathrm{~m}$, Cigna, 2011) can be a useful trick to prevent autotrophic biofilm formation (Cigna, 1993; Mulec \& Kosi, 2009) and wet and soft surfaces should be less illuminated if possible (Rajczy, 1989). Also motion detectors could be used to limit the illumination on the passageways (Hoffmann, 2002). Beside light system renewal, a complex of germicidal lamps with UV irradiation could integrate lampenflora control system, when lights in the passageway are switched off (Cigna, 2011). The removal of green coatings by means of the only brushes and water is expensive and counterproductive, favouring the spread of propagules (Rajczy, 1989). The use of algaecides, antibiotics or sprays, has to be evaluated carefully considering the potential damages on the substrate and effectiveness and costs (Albertano, 1991). Atrazine and simazene seem to be efficient in inhibiting algal growth, but only the latter leaves the wall surface completely discoloured and does not produce fumes (Grobbelaar, 2000). Furthermore, herbicide degradation is often slow and may affect subterranean fauna (Cigna, 2011). The use of butyl alcohol or bleaching solutions requires periodical maintenance (Albertano et al., 2003) and frequently worsens the aspect of the rock walls, sometimes oxidising its iron inclusions (Roldán, 2008). For this reason, chlorine bleach (sodium hypochlorite $\mathrm{NaClO}$ ) and peroxide (hydrogen peroxide, $\mathrm{H}_{2} \mathrm{O}_{2}$ ) appear not adequate in the treatment of walls characterized by prehistoric paintings (Aley, 2004). Moreover, this treatment seems to be not effective against some cyanobacteria that are able to survive in crevices (Iliopoulou-Georgoudaki et al., 1993), like for instance Scytonema julianum (Meneghini ex Franck) Richter. Despite the release of gaseous chlorine with potential consequences on biota (Faimon et al., 2003), chlorine bleach (50\%) is an effective solution and is largely used (Cigna, 1993). Recently, peroxide was also tested as an alternative to chlorine bleach for the removal of lampenflora: $15 \% \mathrm{H}_{2} \mathrm{O}_{2}$ appeared to be effective on its destruction, even if it seems less effective than chlorine bleach (Mulec \& Glažar, 2011). Moreover, at this concentration, peroxide damages limestone and speleothems, reacting with carbonates. To overcome this problem, Faimon et al. (2003) suggested to introduce some limestone fragments in $15 \% \mathrm{H}_{2} \mathrm{O}_{2} 10$ hours before the cleaning procedure. In this way, the saturation of the solution with respect to calcite can be reached, preserving limestone cave walls from deterioration.

The formation of lampenflora as consequence of tourist exploitation of show caves also represents a severe threat for conservation issues, as caves shelter troglobionts, rare and endemic taxa (Mulec et al., 2008; Czerwik-Marcinkowska \& Mrozińska, 2011). The environmental management of show caves should accurately take into consideration which kind of habitat has to be preserved: low and intermediate energy subterranean systems are the most vulnerable and the human presence could easily threaten their natural equilibrium. Indeed, touristic flow should be established by a well-designed program of measurements, including temperature, humidity, $\mathrm{CO}_{2}$ assessment. The flux of tourists in the cave should be regulated, in order to avoid excessive repercussions on the cave environmental parameters, targeting the maintanenace of their natural range of variations. Reasonable recovery periods should be planned in response to excessive impacts.

\section{ACKNOWLEDGEMENTS}

This review is part of the CAVELAB project "From microclimate to climate change: caves as laboratories for the study of the effects of temperature on ecosystems and biodiversity", funded by Compagnia di San Paolo and University of Turin (Progetti di Ricerca di Ateneo 2011 - ORTO11TPXK).

\section{REFERENCES}

Abdullin Sh.R., 2009 - Cyanobacterial-algal cenoses of the Shulgan-Tash cave, Southern Urals. Russian Journal of Ecology, 40: 301-303.

http://dx.doi.org/10.1134/S1067413609040122

Abdullin Sh.R., 2011 - Effect of illumination on the distribution of phototrophic organisms in the entrance part of the Shul'gan-Tash cave. Russian Journal of Ecology, 42: 249-251.

http://dx.doi.org/10.1134/S1067413611030039 
Affan M.A. \& Lee J.B., 2004 - Seasonal characteristics of phytoplankton dynamics and environmental factors in the coast of Mara-do and U-do, Jeju Island, Korea. Algae, 9: 235-245.

Albertano P., 1991 - The role of photosynthetic microorganisms on ancient monuments. A survey on methodological approaches. Journal of the European Study Group on Physical, Chemical, Biological and Mathematical Techniques Applied to Archaeology, Pact, 33: 151-159.

Albertano P., 1993 - Epilithicalgalcommunities in hypogean environments. Giornale Botanico Italiano, 127: 386392. http://dx.doi.org/10.1080/11263509309431020

Albertano P. \& Grilli Caiola M., 1989 - A hypogean algal association. Braun-Blanquetia, 3: 287-292.

Albertano P. \& Urzi C., 1999 - Structural interactions among epilithic cyanobacteria and heterotrophic microorganisms in Roman hypogea. Microbial Ecology, 38: 244-252. http://dx.doi.org/10.1007/s002489900174

Albertano P. \& Bellezza S., 2001 - Cytochemistry of cyanobacterial exopolymers in biofilms from Roman hypogea. Nova Hedwigia, 123: 501-518.

Albertano P., Luongo L. \& Grilli Caiola M., 1991a Observations on cell structure of micro-organisms of an epilithic phototrophic community competing for light. Nova Hedwigia, 53: 369-381.

Albertano P., Luongo L. \& Grilli Caiola M., 1991b-Influence of different lights on mixed cultures of microalgae from ancient frescoes. International Biodeterioration, 27: 2738. http://dx.doi.org/10.1016/0265-3036(91)90021-I

Albertano P., Kováčik L., Marvan P. \& Grilli Caiola M., 1995 - A terrestrial epilithic diatom from Roman catacombs. In: Donato M. \& Montresor M. (Eds.) Proceedings of the Thirteenth International Diatom Symposium Maratea, Italy, 1st - 7th September 1994. Bristol: Biopress Limited: 11-21.

Albertano P., Bruno L., D’Ottavi D., Moscone D. \& Palleschi G., 2000 - Effect of photosynthesis on $p H$ variation in cyanobacterial biofilms from Roman catacombs. Journal of Applied Phycology, 12: 379-384. http://dx.doi.org/10.1023/A:1008149529914

Albertano P., Moscone D., Palleschi G., Hermosin B., Saiz-Jimenez C., Sanchez-Moral S., HernándezMariné M., Urzi C., Groth I., Schroeckh V., Saarela M., Mattila-Sandholm T., Gallon J.R., Graziottin F., Bisconti F. \& Giuliani R., 2003 - Cyanobacteria attack rocks (CATS): Control and preventive strategies to avoid damage caused by cyanobacteria and associated microorganisms in Roman hypogean monuments. In: Saiz-Jimenez C. (Ed.) - Molecular Biology and Cultural Heritage. Lisse: Swets \& Zeitlinger B.V.: 151-162.

Albertano P., Bruno L. \& Bellezza S., 2005 - New strategies for the monitoring and control of cyanobacterial films on valuable lithic faces. Plant Biosystems, 139: 311-322. http:/ / dx.doi.org/10.1080/11263500500342256

Aley T., 2004 - Tourist caves: algae and lampenflora. In: Gunn J. (Ed.) - Encyclopedia of Caves and Karst Science. New York: Fitzroy Dearborn: 1568-1570.

Almeida S.F.P. \& Gil M.C.P., 2001 - Ecology of freshwater diatoms from the central region of Portugal. Cryptogamie Algologie, 22: 109-126. http://dx.doi.org/10.1016/S0181-1568(01)01053-4

Altieri A., Pietrini A.M. \& Ricci S., 1993 - Un'associazione di alghe e muschi in un sito archeologico ipogeo. Giornale Botanico Italiano, 127: 611.

Alvarez Cobelas M. \& Estévez García A., 1982 - Catálogo de las algas continentales españolas I. Diatomophyceae Rabenhorst 1864. Lazaroa, 4: 269-285.
Ariño X., Hernández-Mariné M. \& Saiz-Jimenez C., 1997 - Colonization of Roman tombs by calcifying cyanobacteria. Phycologia, 36: 366-373.

http://dx.doi.org/10.2216/i0031-8884-36-5-366.1

Asencio A.D. \& Aboal M., 2000a - A contribution to knowledge of chasmoendolithic algae in cave-like environments. Algological Studies, 98: 133-151.

Asencio A.D. \& Aboal M., 2000b. - Algae from La Serreta cave (Murcia, SE Spain) and their environmental conditions. Algological Studies, 96: 59-78.

Asencio A.D. \& Aboal M., 2001 - Biodeterioration of wall paintings in caves of Murcia (SE Spain) by epilithic and chasmoendolithic microalgae. Algological Studies, 103: 131-142.

Bahls L.L., 1981 - Diatoms of Lewis and Clark Caverns. Proceedings of the Montana Academy of Sciences, 40: 11-18.

Baker A. \& Genty D., 1998 - Environmental pressures on conserving cave speleothems: effects of changing surface land use and increased cave tourism. Journal of Environmental Management, 53: 165-175. http://dx.doi.org/10.1006/jema.1998.0208

Balch E.S., 1900 - Glacières or Freezing Caverns. Philadelphia: Allen, Lane and Scott, 337 p.

Barr T.C., 1968 - Ecological studies in the Mammoth Cave system of Kentucky I. The biota. International Journal of Speleology, 3: 147-204. http://dx.doi.org/10.5038/1827-806X.3.1.10

Barton H.A. \& Northup D.E., 2007 - Geomicrobiology in cave environments: past, current and future perspectives. Journal of Cave and Karst Studies, 69: 163-178.

Bellezza S., Paradossi G., De Philippis R. \& Albertano P., 2003 - Leptolyngbya strains from Roman hypogea: cytochemical and physico-chemical characterisation of exopolysaccharides. Journal of Applied Phycology, 15: 193-200. http://dx.doi.org/10.1023/A:1023811311686

Bellezza S., Albertano P., de Philippis R. \& Paradossi G., 2006 - Exopolysaccharides of two cyanobacterial strains from Roman hypogea. Geomicrobiology Journal, 23: 301-310. http://dx.doi.org/10.1080/01490450600761904

Bertolani M. \& Cigna A.A., 1993 - Activity of the scientific commission of "Grotta Grande del Vento" (Genga, Ancona, Central Italy). International Journal of Speleology, 22: 51-60.

Blanco S. \& Ector L., 2009 - Distribution, ecology and nuisance effects of the freshwater invasive diatom Didymosphenia geminata (Lyngbye) M. Schmidt: a literature review. Nova Hedwigia, 88: 347-422.

http://dx.doi.org/10.1127/0029-5035/2009/0088-0347

Blanco S., Cejudo-Figueiras C., Álvarez-Blanco I., Bécares E., Hoffmann L. \& Ector L., 2010 - Atlas de las Diatomeas de la Cuenca del Duero / Diatom Atlas of the Duero Basin. $1^{a}$ ed., Área de Publicaciones, Universidad de León, León, 382 p.

Bock W., 1963 - Diatomeen extrem trockener Standorte. Nova Hedwigia, 5: 199-254.

Bock W., 1970 - Felsen und Mauernals Diatomeenstandorte. Beihefte zur Nova Hedwigia, 31: 395-441.

Braack L.E.O., 1989 - Arthropod inhabitants of a tropical cave "island" environment provisioned by bats. Biological Conservation, 48: 77-84. http://dx.doi.org/10.1016/0006-3207(89)90027-X

Bruno L., Billi D., Albertano P. \& Urzi C., 2006 - Genetic characterization of epilithic cyanobacteria and their associated bacteria. Geomicrobiology Journal, 23: 293299. http://dx.doi.org/10.1080/01490450600760732

Bruno L., Billi D., Bellezza S. \& Albertano P., 2009 - Cytomorphological and genetic characterization of troglobitic Leptolyngbya strains isolated from Roman hypogea. Applied and Environmental Microbiology, 75: 608-617. http://dx.doi.org/10.1128/AEM.01183-08 
Buczkó K., 2003 - Diadesmis brekkaensoides (W. Bock) Moser, Lange-Bertalot et Metzeltin: a new aerophytic diatom for the Hungarian flora. Studia Botanica Hungarica, 34: 5-10.

Buczkó K. \& Rajczy M., 1989 - Contributions to the flora of the Hungarian caves II. Flora of three caves near Beremend, Hungary. Studia Botanica Hungarica, 21: 13-26.

Buczkó K. \& Németh J., 2009 - Contribution to the knowledge of Cyanobacteria and the algal flora of the Aggtelek National Park. In: Papp B. (Ed.) - Flora of the Aggtelek National Park, Cryptogams. Budapest: Hungarian Natural History Museum: 13-32.

Cañaveras J.C., Sanchez-Moral S., Soler V. \& Saiz-Jimenez C., 2001 - Microorganisms and microbially induced fabrics in cave walls. Geomicrobiology Journal, 18: 223-240. http://dx.doi.org/10.1080/01490450152467769

Carter J.R., 1971 - Diatoms from the Devil's Hole Cave Fife, Scotland. Nova Hedwigia, 21: 657-681.

Cennamo P., Marzano C., Ciniglia C., Pinto G., Cappelletti P., Caputo P. \& Pollio A., 2012 - A survey of the algal flora of anthropogenic caves of Campi Flegrei (Naples, Italy) archeological district. Journal of Cave and Karst Studies, 74: 243-250. http://dx.doi.org/10.4311/2011JCKS0194

Chang T.-P. \& Chang-Schneider H., 1991 - Algen in vier süddeutschen Höhlen. Berichte der Bayerischen Botanischen Gesellschaft, 62: 221-229.

Cheeptham N., 2013 - Advances and challenges in studying cave microbial diversity. In: Cheeptham N. (Ed.) - Cave Microbiomes: A Novel Resource for Drug Discovery. New York, Heidelberg, Dordrecht, London: Springer: 1-34. http://dx.doi.org/10.1007/978-1-4614-5206-5_1

Cigna A.A., 1993 - Environmental management of tourist caves. The examples of Grotta di Castellana and Grotta Grande del Vento, Italy. Environmental Geology, 21: 173-180. http://dx.doi.org/10.1007/BF00775302

Cigna A.A., 2011 - The problem of lampenflora in show caves. In: Bella P. \& Gazik P. (eds.) - Proceedings of the 6th ISCA Congress, SNC of Slovak Republic, Slovak Caves Administration: 201-205.

Claus G., 1955 - Algae and their mode of life in the Baradla cave at Aggtelek. Acta Botanica Academiae Scientiarum Hungaricae, 2: 1-26.

Claus G., 1962a - Data on the ecology of the algae of Peace cave in Hungary. Nova Hedwigia, 4: 55-79.

Claus G., 1962b - Beiträge zur Kenntnis der Algenflora der Abaligeter Höhle. Hydrobiologia, 19: 192-222. http:/ /dx.doi.org/10.1007/BF00146362

Claus G., 1964 - Algae and their mode oflife in the Baradla cave at Aggtelek II. International Journal of Speleology, 1: 13-17. http://dx.doi.org/10.5038/1827-806X.1.1.2

Claus G., 1965 - Daten zur Kenntnis der Algenflora der Höhle Kölyuk von Mánfa. International Journal of Speleology, 1: 541-551.

http://dx.doi.org/10.5038/1827-806X.1.4.8

Compagnone D., Di Carlo V., Bruno L., Albertano P. \& Palleschi G., 1999 - Development of oxygen microsensors for monitoring cyanobacterial photosynthesis in Roman hypogea. Analytical Letters, 32: 213-222.

http://dx.doi.org/10.1080/00032719908542816

Couté A. \& Chauveau O., 1994 - Algae. In: Juberthie C. \& Decu V. (Eds.) - Encyclopaedia Biospeologica, 1: 371-380. Société de Biospéléologie. Moulis - Bucarest.

Cox E.J., 2006 - Raphe loss and spine formation in Diadesmis gallica (Bacillariophyta) - an intriguing example of phenotypic polymorphism in a diatom. Nova Hedwigia Beiheft, 130: 163-175.

Culver D.C. \& Pipan T., 2009 - The Biology of Caves and Other Subterranean Habitats. Oxford University Press, Oxford, 254 p.
Czerwik-Marcinkowska J. \& Mrozińska T., 2009 - Epilithic algae from caves of the Krakowsko-Czestochowska Upland (Southern Poland). Acta Societatis Botanicorum Poloniae, 78: 301-309. http://dx.doi.org/10.5586/asbp.2009.040

Czerwik-Marcinkowska J. \& Mrozińska T., 2011 - Algae and cyanobacteria in caves of the Polish Jura. Polish Botanical Journal, 56: 203-243.

Darienko T. \& Hoffmann L., 2006 - Diversity and ecology of sandstone-inhabiting algae in casemates of Luxembourg. International Journal on Algae, 8: 109128. http://dx.doi.org/10.1615/InterJAlgae.v8.i2.10

Dayner D.M. \& Johansen J.R., 1991 - Observations on the algal flora of Seneca Cavern, Seneca County, Ohio. Ohio Journal of Science, 91: 118-121.

Denys L., 2009 - Palaeolimnology without a core: 153 years of diatoms and cultural environmental change in a shallow lowland lake (Belgium). Fottea, 9: 317-332.

Denys L. \& Carter J.R., 1989 - The diatom Navicula genustriata Hustedt: valve morphology, variability and notes on its ecology. Diatom Research, 4: 9-19. http:/ /dx.doi.org/10.1080/0269249X.1989.9705047

Denys L. \& De Smet W.H., 1996 - Observations on the subaerial diatom Navicula spinifera Bock, and its transfer to Luticola Mann. Cryptogamie Algologie, 17: 77-93.

DobàtK., 1963 - "Höhlenalgen" bedrohen dieEiszeitmalereien von Lascaux. Die Höhle, Wien, 14: 41-45.

Dobàt K., 1966 - Die Kryptogamenvegetation der Höhlen und Halbhöhlen im Bereich der Schwäbischen Alb. Abhandlungen zur Karst- und Höhlenkunde, Reihe E, Botanik, 3: 1-153.

Dobàt K., 1970 - Considérations sur la végétation cryptogamique des grottes du Jura Souabe (sud-ouest de l'Allemagne). Annales de Spéléologie, 25: 871-907.

Elias C.L., Vieira N., Feio M.J. \& Almeida S.F.P., 2012 - Can season interfere with diatom ecological quality assessment? Hydrobiologia, 695: 223-232. http://dx.doi.org/10.1007/s10750-012-1196-8

Elliot W.R., 2006 - Biological dos and don'ts for cave restoration and conservation. In: Hildreth-Werker V. \& Werker J. (Eds.) - Cave Conservation and Restoration. Huntsville: National Speleological Society: 33-42.

Ettl H. \& Gärtner G., 1995 - Syllabus der Boden-, Luft- und Flechtenalgen.- Gustav Fischer Verlag, Stuttgart, $721 \mathrm{p}$.

Faimon J., Štelcl J., Kubesǒva S. \& Zimák J., 2003 Environmentally acceptable effect of hydrogen peroxide on cave "lamp-flora", calcite speleothems and limestones. Environmental Pollution, 122: 417-422. http://dx.doi.org/10.1016/S0269-7491(02)00309-3

Garbacki N., Ector L., Kostikov I. \& Hoffmann L., 1999 Contribution à l'étude de la flore des grottes de Belgique. Belgian Journal of Botany, 132: 43-76.

Germain H., 1935 - Flore diatomique des caves du Musée Saint-Jean, à Angers. Bulletin de la Société Botanique de France, 82: 43-47.

Germain H., 1936 - Les lieux de développement et de multiplication des diatomées d'eau douce. Contribution à l'écologie des diatomées. Travaux du Laboratoire de Botanique de 1'Université Catholique d'Angers $\mathrm{N}^{\circ} 6$. Bulletin des Sciences Naturelles de l'Ouest, Nantes, sér. 5, 6: 1-200, 16 pls.

Germain H., 1981 - Flore des diatomées Diatomophycées eaux douces et saumâtres du Massif Armoricain et des contrées voisines d'Europe occidentale. Société Nouvelle des Éditions Boubée, Paris, 444 p.

Giordano M., Mobili F., Pezzoni V., Hein M.K. \& Davis J.S., 2000 - Photosynthesis in the caves of Frasassi (Italy). Phycologia, 39: 384-389.

http://dx.doi.org/10.2216/i0031-8884-39-5-384.1 
Granetti B., 1978 - Struttura di alcune valve teratologiche di Navicula gallica (W. Smith) Van Heurck. Giornale Botanico Italiano, 112: 1-12.

http://dx.doi.org/10.1080/11263507809426604

Grilli Caiola M., Forni C. \& Albertano P., 1987 Characterization of the algal flora growing on ancient Roman frescoes. Phycologia, 26: 387-390. http://dx.doi.org/10.2216/i0031-8884-26-3-387.1

Grobbelaar J.U., 2000 - Lithophytic algae: A major threat to the karst formation of show caves. Journal of Applied Phycology, 12: 309-315.

http://dx.doi.org/10.1023/A:1008172227611

Gunn J., Hardwick P. \& Wood P.J., 2000 - The invertebrate community of the Peak-Speedwell cave system, Derbyshire, England - pressures and considerations for conservation management. Aquatic Conservation: Marine and Freshwater Ecosystems, 10: 353-369. http://dx.doi.org/10.1002/10990755(200009/10)10:5<353::AID-AQC413>3.0.CO;2-S

Haak P., Frisch R., Hacker M. \& Morgan R., 2002 Identification of a bacterium isolated from Mammoth Cave, Mammoth Cave National Park, Kentucky, USA that produces an extracellular anti-angiogenesis substance. 102nd General Meeting of the American Society for Microbiology, Salt Lake City, Utah, May 19-23, 2002.

Hahn A. \& Neuhaus W., 1997 - Boden-Diatomeen einer landwirtschaftlichen Nutzfläche bei Potsdam, Deutschland. Nova Hedwigia 65: 285-298.

Hajdu L., 1966 - Algological studies in the cave of Mátyás Mount, Budapest, Hungary. International Journal of Speleology, 2: 137-149.

http://dx.doi.org/10.5038/1827-806X.2.1.12

Hernández-Mariné M., Roldán M., Clavero E., Canals A. \& Ariño X., 2001 - Phototrophic biofilm morphology in dim light. The case of the Puigmolto sinkhole. Nova Hedwigia Beiheft, 123: 237-254.

Hernández-Mariné M., Clavero E. \& Roldán M., 2003 Why there is such luxurious growth in the hypogean environments. Algological Studies, 109: 229-239.

http://dx.doi.org/10.1127/1864-1318/2003/0109-0229

Hoffmann L., 1989 - Algae of terrestrial habitats. The Botanical Review, 55: 77-105.

http://dx.doi.org/10.1007/BF02858529

Hoffmann L., 2002 - Caves and otherlow-lightenvironments: aerophitic photoautotrophic microorganisms. In Bitton G. (Ed.) - Encyclopedia of Environmental Microbiology. New York: John Wiley \& Sons: 835-843.

Hoffmann L. \& Darienko T., 2005 - Algal biodiversity on sandstone in Luxembourg. Ferrantia, 44: 99-101.

Hofmann G., Werum M. \& Lange-Bertalot H., 2011 Diatomeen im Süßwasser-Benthos von Mitteleuropa. Bestimmungsflora Kieselalgen für die ökologische Praxis. Über 700 der häufigsten Arten und ihre Ökologie. A.R.G. Gantner Verlag. K.G., Rugell, 908 p.

Holsinger J.R., 1998 - Troglobites: the evolution of cavedwelling organisms. American Scientist, 76: 146-153.

Houk V., 2003 - Atlas of freshwater centric diatoms with a brief key and descriptions. Part I. Melosiraceae, Orthoseiraceae, Paraliaceae and Aulacoseiraceae. In: Poulíčková A. (Ed.) - Czech Phycology Supplement Vol. 1, Palacký University Press, Olomouc: 115 p.

Hustedt F., 1930 - Die Kieselalgen Deutschlands, Österreichs und der Schweiz unter Berücksichtigung der übrigen Länder Europas sowie der angrenzenden Meeresgebiete. 1. Teil. Reprint 1977, Otto Koeltz science publisher: $920 \mathrm{p}$.

Iliopoulou-Georgoudaki J., Pantazidou A. \& Theoulakis P., 1993 - An assessment of cleaning photoautotropic microflora: The case of "Perama" cave, Ioannina Greece. Mémoires de Biospéologie, 20: 117-120.
Imprescia U., 1983 - Considerazioni teoriche sulla radiazione emessa de vari tipi di lampade, in relazione alla formazione e alla crescita di alghe e muschi sulle pareti illuminate di grotte turistiche. Le Grotte d'Italia, 4: 93-101.

Johansen J.R., 1999 - Diatoms of aerial habitats. In: Smol J.P. \& Stoermer E.F. (Eds.) - The Diatoms. Applications for the Environmental and Earth Sciences. Cambridge: Cambridge University Press: 264-273.

Jones H.J., 1964 - Algological investigations in Mammoth Cave, Kentucky. International Journal of Speleology, 1 (4): 491-517. http://dx.doi.org/10.5038/1827-806X.1.4.6

Kashima N., Irie T. \& Kinoshita N., 1987 - Diatom, contributors of coralloid speleothems, from TogawaSakaidani-do cave in Miyazaki Prefecture, Central Kyushu, Japan. International Journal of Speleology, 16: 95-100. http://dx.doi.org/10.5038/1827-806X.16.3.3

Kawecka B., 1989 - Sessile algal communities in a mountain stream in conditions of light gradation during its flow through a cave (West Tatra, Poland). Acta Hydrobiologica, 31: 35-42.

Kelly M., King L. \& Chatháin N.I., 2009 - The conceptual basis of ecological-status assessments using diatoms. Biology \& Environment Proceedings of the Royal Irish Academy, 109: 175-189.

Kociolek J.P., Stepanek J.G., Lowe R.L., Johansen J.R. \& Sherwood A.R., 2013 - Molecular data show the enigmatic cave-dwelling diatom Diprora (Bacillariophyceae) to be a raphid diatom. European Journal of Phycology, 48: 474-484.

http://dx.doi.org/10.1080/09670262.2013.860239

Kofoid C.A., 1900 - The plankton of Echo River, Mammoth Cave. Transactions of the American Microscopical Society, 21: 113-126. http://dx.doi.org/10.2307/3221035

Kol E., 1957 - Algológiai vizsgálatok a Sátorhegység jeges barlangjában [Algological investigations in the ice-cave of the Sátor mountain]. Botanikai Közlemények, 47: 43-50.

Kol E., 1964 - The microvegetation of a small ice-cave in Hungary. International Journal of Speleology, 1: 19-24. http://dx.doi.org/10.5038/1827-806X.1.1.3

Kopalová K., Elster J., Nedbalová L. \& Van de Vijver B., 2009 - Three new terrestrial diatom species from seepage areas on James Ross Island (Antarctic Peninsula Region). Diatom Research, 24: 113-122. http://dx.doi.org/10.1080/0269249X.2009.9705786

Kopalová K., Nedbalová L., de Haan M. \& Van de Vijver B., 2011 - Description of five new species of the diatom genus Luticola (Bacillariophyta, Diadesmidaceae) found in lakes of James Ross Island (Maritime Antarctic Region). Phytotaxa, 27: 44-60.

Krammer K., 1997 - Die cymbelloiden Diatomeen. Eine Monographie der weltweit bekannten Taxa. Teil 2. Encyonema part., Encyonopsis and Cymbellopsis. Bibliotheca Diatomologica, 37: 1-463.

Krammer K., 2000 - The genus Pinnularia. In: LangeBertalot H. (Ed.) - Diatoms of Europe. Diatoms of the European Inland Waters and Comparable Habitats. Volume 1. Ruggel: ARG Gantner Verlag K.G., 703 p.

Krammer K. \& Lange-Bertalot H., 1986 - Bacillariophyceae 1. Teil: Naviculaceae. In: Ettl H., Gerloff J., Heynig H. \& Mollenhauer D. (Eds.) - Süßwasserflora von Mitteleuropa. Band 2/1. Stuttgart: Gustav Fisher Verlag: 876 p.

Krammer K. \& Lange-Bertalot H., 1988 - Bacillariophyceae 2. Teil: Bacillariaceae, Epithemiaceae, Surirellaceae. In: Ettl H., Gerloff J., Heynig H. \& Mollenhauer D. (Eds.) Süßwasserflora von Mitteleuropa. Band 2/2. Stuttgart: Gustav Fisher Verlag: 596 p.

Krammer K. \& Lange-Bertalot H., 1991 - Bacillariophyceae 3. Teil: Centrales, Fragilariaceae, Eunotiaceae. In: Ettl H., Gerloff J., Heynig H. \& Mollenhauer D. (Eds.) Süßwasserflora von Mitteleuropa. Band 2/3. Stuttgart: Gustav Fisher Verlag: 576 p. 
Krivograd Klemenčič A. \& Vrhovšek D., 2005 - Algal flora of Krška Jama cave, Slovenia. Acta Musei Nationalis Pragae, Series B, Historia Naturalis, 61: 77-80.

Kulikovskiy M.S., Lange-Bertalot H., Witkowski A., Dorofeyuk N.I. \& Genkal S.I., 2010 - Diatom assemblages from Sphagnum bogs of the world I. Nur bog in northern Mongolia. Bibliotheca Diatomologica, 55: 1-326.

Lamprinou V., Hernández-Mariné M., Canals T., Kormas K., Economou-Amilli A. \& Pantazidou A., 2011 - Morphology and molecular evaluation of Iphinoe spelaeobios gen. nov., sp. nov. and Loriellopsis cavernicola gen. nov., sp. nov., two stigonematalean cyanobacteria from Greek and Spanish caves. International Journal of Systematic and Evolutionary Microbiology, 61: 2907-2915. http://dx.doi.org/10.1099/ijs.0.029223-0

Lange-Bertalot H., 1993 - 85 Neue Taxa und über 100 weitere neu definierte Taxa ergänzend zur Süßwasserflora von Mitteleuropa Vol. 2/ 1-4. Bibliotheca Diatomologica, 27: 1-454.

Lange-Bertalot H. \& Werum M., 2001 - Diadesmis fukushimae $s p$. nov. and some other new or rarely observed taxa of the subgenus Paradiadesmis LangeBertalot \& Le Cohu. Diatom, 17: 3-19.

Lauriol B., Clark I.D. \& Prevost C., 1995 - Étude d'une glace de la fin de l'hypsithermal dans une caverne du nord du Yukon, Canada. In: Griselin M. (Ed.) - Actes $d u 3^{e}$ symposium international Cavités glaciaires et cryokarst en régions polaires et de hautes montagnes, Chamonix-France, 1994. Annales littéraires de l’Université de Besançon, 561: 89-92.

Lauriol B., Prévost C. \& Lacelle D., 2006 - The distribution of diatom flora in ice caves of the northern Yukon Territory, Canada: relationship to air circulation and freezing. International Journal of Speleology, 35: 83-92. http://dx.doi.org/10.5038/1827-806X.35.2.4

Lavoie I., Hamilton P.B., Campeau S., Grenier M. \& Dillon P.J., 2008 - Guide d'Identification des Diatomées des Rivières de 1'Est du Canada. Presses de 1'Université du Québec, Québec, 241 p.

Le Cohu R. \& Van de Vijver B., 2002 - Le genre Diadesmis (Bacillariophyta) dans les archipels de Crozet et de Kerguelen avec la description de cinq espèces nouvelles. Annales de Limnologie - International Journal of Limnology, 38: 119-132.

http://dx.doi.org/10.1051/limn/2002010

Lee N.M., Meisinger D.B., Aubrecht R., Kováčik L., SaizJimenez C., Baskar S., Baskar R., Liebl W., Porter M.L. \& Engel A.S., 2012 - Caves and karst environments. In: Bell E.M. (Ed.) - Life at Extremes: Environments, Organisms and Strategies for Survival. Wallingford: CAB International: 320-344.

http://dx.doi.org/10.1079/9781845938147.0320

Levkov Z., Metzeltin D. \& Pavlov A., 2013 - Luticola and Luticolopsis. In: Lange-Bertalot H. (Ed.) - Diatoms of Europe. Diatoms of the European Inland Waters and Comparable Habitats. Volume 7. Ruggel: ARG Gantner Verlag K.G., 697 p.

Llop E., Alvaro I., Hernández-Mariné M., Sammut S. \& Gómez-Bolea A., 2012 - Colonization of Maltese catacombs by phototrophic biofilms. How much does light matter? International Journal of Heritage in the Digital Era, 1: 289-294. http://dx.doi.org/10.1260/2047-4970.1.0.289

Long A.J., Woodroffe S.A., Milne G.A., Bryant C.L. \& Wake L.M., 2010 - Relative sea level change in west Greenland during the last millennium. Quaternary Science Reviews, 29: 367-383. http://dx.doi.org/10.1016/j.quascirev.2009.09.010

Lowe R.L., 2011 - The importance of scale in understanding the natural history of diatom communities. In: Seckbach J. \& Kociolek J.P. (Eds.) - The Diatom World. Cellular Origin, Life in Extreme Habitats and Astrobiology 19. New York: Springer: 293-311.
Lowe R.L., Furey P.C., Ress J.A. \& Johansen J.R., 2007 Diatom biodiversity and distribution on wetwalls in Great Smoky Mountains National Park. Southeastern Naturalist, 6 (Special Issue 1): 135-152.

Lowe R.L., Kociolek J.P., Johansen J.R., Van de Vijver B., Lange-Bertalot H. \& Kopalová K., 2014 - Humidophila gen. nov., a new genus for a clade of diatoms (Bacillariophyta) formerly within the genus Diadesmis: species from Hawai'i, including one new species. Diatom Research, 29. http://dx.doi.org/10.1080/0269249X.2014.889039

Lund J.W.G., 1946 - Observations on soil algae. I. The ecology, size and taxonomy of British soil diatoms. New Phytologist, 45: 56-110. http://dx.doi.org/10.1111/j.1469-8137.1946.tb05047.x

Lundberg J., McFarlane D.A. \& Brewer-Carias C., 2010 - An extraordinary example of photokarren in a sandstone cave, Cueva Charles Brewer, Chimantá Plateau, Venezuela: Biogeomorphology on a small scale. Geomorphology, 121: 342-357.

http://dx.doi.org/10.1016/j.geomorph.2010.05.005

Main S.P., 2003 - Diprora haenaensis gen. et sp. nov., a filamentous, pseudoaerial, araphid diatom from Kaua' $i$ (Hawaiian Islands). Diatom Research, 18: 259-272. http://dx.doi.org/10.1080/0269249X.2003.9705591

Mann S.L., Steidl R.J. \& Dalton V.M., 2002 - Effects of cave tours on breeding Myotis velifer. Journal of Wildlife Management, 66: 618-624. http://dx.doi.org/10.2307/3803128

Mason Williams M.A., 1967 - Further investigations into bacterial and algal populations of caves in South Wales. International Journal of Speleology, 2: 389-395. http://dx.doi.org/10.5038/1827-806X.2.4.10

Mazina S.E., \& Maximov V.N., 2011 - Photosynthetic organism communities of the Akhshtyrskaya excursion cave. Moscow University Biological Sciences Bulletin, 66: 37-41. http://dx.doi.org/10.3103/S009639251101007X

McCune B. \& Mefford M.J., 2011 - PC-ORD. Multivariate Analysis of Ecological Data. Version 6.0 MjM Software, Gleneden Beach, Oregon, U.S.A.

Mitra A.K., Banerjee A., Sinha S. \& Chakraborty A., 2012 - Characterization of a cyanobacterial colony from an artificially illuminated speleothem cave in Andhra Pradesh. Plant Sciences Feed, 2: 11-14.

Moore G.W., 1952 - Speleothem - A new cave term. National Speleological Society News, 10: 2.

Mulec J., 2012 - Lampenflora. In: White W.B. \& Culver D.C. (Eds.) - Encyclopedia of Caves. Amsterdam: Academic Press: 451-456.

http://dx.doi.org/10.1016/B978-0-12-383832-2.00064-5

Mulec J. \& Kosi G., 2008 - Algae in the aerophytic habitat of Račiške ponikve cave (Slovenia). Natura Sloveniae, 10: 39-49.

Mulec J. \& Kosi G., 2009 - Lampenflora algae and methods of growth control. Journal of Cave and Karst Studies, 71: 109-115.

Mulec J. \& Glažar S., 2011 - First results on use of a hydrogen peroxide solution in Postojnska Jama (Slovenia) to remove lampenflora. Proceedings of the 6th ISCA Congress, SNC of Slovak Republic, Slovak Caves Administration: 128-131.

Mulec J., Kosi G. \& Vrhovšek D., 2008 - Characterization of cave aerophytic algal communities and effects of irradiance levels on production of pigments. Journal of Cave and Karst Studies, 70: 3-12.

Nagy J.P., 1965 - Preliminary note on the algae of Crystal Cave, Kentucky. International Journal of Speleology, 1: 479-490. http://dx.doi.org/10.5038/1827-806X.1.4.5 Norbäck Ivarsson L., Ivarsson M., Lundberg J., Sallstedt T. \& Rydin C., 2013 - Epilithic and aerophilic diatoms in the artificial environment of Kungsträdgården metro station, Stockholm, Sweden. International Journal of Speleology, 42: 289-297.

http://dx.doi.org/10.5038/1827-806X.42.3.12 
Northup D.E. \& Lavoie K.H., 2001 - Geomicrobiology of caves: a review. Geomicrobiology Journal, 18: 199222. http://dx.doi.org/10.1080/01490450152467750

Padisák J., Rajczy M., P.-Komáromy Zs. \& Hazslinszky T., 1984 - Experiments on algae and mosses developing around different lamps in the cave "Pál-völgyi-barlang". In: Hazslinszky T. (Ed.) - Proceedings of the International Colloquium on lamp flora, Budapest, 10-13 October, 1984: 83-102.

Palik P., 1960 - A barlangok algavilágáról (Study into the algal flora of caves). Hidrológiai Közlöny, 40: 417-422.

Palik P., 1966 - Algae from the cave of Mátyás Mount, Budapest, Hungary. International Journal of Speleology, 2: 155-164. http://dx.doi.org/10.5038/1827-806X.2.1.14

Passauer U., 1996 - Chrysosplenium alternifolium L. in der Lurgrotte - erstmals eine Blütenpflanze in einer "Lampenflora". Annalen des Naturhistorischen Museums in Wien, 98 B Suppl.: 51-56.

Passy S.I., 2007 - Diatom ecological guilds display distinct and predictable behavior along nutrient and disturbance gradients in running waters. Aquatic Botany, 86: 171-178. http://dx.doi.org/10.1016/j.aquabot.2006.09.018

Patrick R., 1948 - Factors affecting the distribution of diatoms. The Botanical Review, 14: 473-524. http://dx.doi.org/10.1007/BF02861575

Patrick R., 1977 - Ecology of freshwater diatoms and diatom communities. In: Werner D. (ed.) - Botanical Monographs. Volume 13. The Biology of Diatoms. Berkeley \& Los Angeles: University of California Press: 284-332.

Patrick R. \& Reimer C., 1966 - The Diatoms of the United States exclusive of Alaska and Hawaii, Vol. 1. Monographs of The Academy of Natural Sciences of Philadelphia, No. 13, Philadelphia, PA. 688 p.

Pentecost A., 1998 - The significance of calcite (travertine) formation by algae in a moss-dominated travertine from Matlock Bath, England. Archiv für Hydrobiologie, 143: 487-509.

Petersen J.B., 1928 - The aërial Algae of Iceland. In: Rosenvinge L.K. \& Warming E. (Eds.) - The Botany of Iceland, Vol. 2, no. 8. J. Frimodt, Copenhagen: 325-447.

Pfister L., McDonnell J.J., Wrede S., Hlúbiková D., Matgen P., Fenicia F., Ector L. \& Hoffmann L., 2009 - The rivers are alive: on the potential for diatoms as a tracer of water source and hydrological connectivity. Hydrological Processes, 23: 2841-2845.

http://dx.doi.org/10.1002/hyp.7426

P.-Komáromy Zs., 1977 - The algal flora of the Ördöglyuk Cave at Szoplak (Hungary). Annales Historico-Naturales Musei Nationalis Hungarici, 69: 29-35.

P.-Komáromy Zs., Padisák J. \& Rajczy M., 1985 - Flora in the lamp-lit areas of the cave "Anna-barland" near Lillafüred (Hungary). Annales Historico-Naturales Musei Nationalis Hungarici, 77: 103-112.

Poulíčková A., 2008 - Morphology, cytology and sexual reproduction in the aerophytic cave diatom Luticola dismutica (Bacillariophyceae). Preslia, 80: 87-99.

Poulíčková A. \& Hašler P., 2007 - Aerophytic diatoms from caves in central Moravia (Czech Republic). Preslia, 79: 185-204.

Poulson T.L. \& Lavoie K.H., 2000 - The trophic basis of subsurface ecosystems. In: Wilkens H., Culver D.C. \& Humphreys W.F. (Eds.) - Ecosystems of the World, vol. 30. Subterranean Ecosystems. Amsterdam: Elsevier: 231-249.

Prøsch-Danielsen L., 1997 - New light on the Holocene shore displacement curve on Lista, the southernmost part of Norway. Norsk Geografisk Tidsskrift - Norwegian Journal of Geography, 51: 83-101.

Rajczy M., 1989 - The flora of Hungarian caves. Karszt és Barlang, Special Issue 1989, Budapest, 69-72.
Rajczy M. \& Buczkó K., 1989 - The development of the vegetation in lamplit areas of the cave Szemlöhegyi-barlang, Budapest, Hungary. In: Kósa A. (Ed.) - Proceedings of the 10th International Congress of Speleology. Budapest: Hungarian Speleological Society: 514-516.

Rajczy M., Padisák J. \& P.-Komáromy Zs., 1984 Flora in the lamp-areas of the caves near Lillafüred. Proceedings of the International Colloquium on lamp flora, Budapest, 10-13 October, 1984: 27-41.

Rajczy M., Buczkó K. \& P.-Komáromy Zs., 1986 Contributions to the flora of the Hungarian caves I. Flora of the entrances of the caves Lök-völgyi-barlang and Szeleta-barlang. Studia Botanica Hungarica, 19: 79-88.

Reichardt E., 1985 - Diatomeen an feuchten Felsen des Südlichen Frankenjuras. Berichte der Bayerischen Botanischen Gesellschaft, 56: 167-187.

Reichardt E., 2004 - Eine bemerkenswerte Diatomeenassoziation in einem Quellhabitat im Grazer Bergland, Österreich. Ein Beitrag zur Kenntnis seltener und wenig bekannter Diatomeen. Iconographia Diatomologica, 13: 419-479.

Riding R., 2000 - Microbial carbonates: the geological record of calcified bacterial-algal mats and biofilms. Sedimentology, 47 179-214.

http://dx.doi.org/10.1046/j.1365-3091.2000.00003.x

Rimet F. \& Bouchez A., 2012 - Life-forms, cell-sizes and ecological guilds of diatoms in European rivers. Knowledge and Management of Aquatic Ecosystems, 406: 1-12. http://dx.doi.org/10.1051/kmae/2012018

Roldán M., 2008 - Caracterització De Biofilms Fototròfics D'Ambients Hipogeus. PhD Thesis, Facultat de Farmàcia, Universitat de Barcelona: 294 p.

Roldán M. \& Hernández-Mariné M., 2009 - Exploring the secrets of the three-dimensional architecture of phototrophic biofilms in caves. International Journal of Speleology, 38: 41-53.

http://dx.doi.org/10.5038/1827-806X.38.1.5

Roldán M., Clavero E., Canals T., Gómez-Bolea A., Ariño X. \& Hernández-Mariné M., 2004 - Distribution of phototrophic biofilms in cavities (Garraf, Spain). Nova Hedwigia, 78: 329-351.

http://dx.doi.org/10.1127/0029-5035/2004/0078-0329

Romero A., 2009 - Cave Biology: Life in Darkness. Cambridge University Press, Cambridge, 306 p. http://dx.doi.org/10.1017/CBO9780511596841

Rushforth S.R., Kaczmarska I. \& Johansen J.R., 1984 - The subaerial diatom flora of Thurston Lava Tube, Hawaii. Bacillaria, 7: 135-157.

Saiz-Jimenez C., 2010 - Painted materials. In: Mitchell R. \& McNamara C.J. (Eds.) - Cultural Heritage Microbiology: Fundamental Studies in Conservation Science. Washington: ASM Press: 3-13.

Sasowsky I.D. \& Palmer M.V., 1994 - Breakthroughs in karst geomicrobiology and redox geochemistry. Abstracts and field trip guide for the symposium held February 16 through 19, 1994. Colorado Springs, Colorado. The Karst Waters Institute, Charles Town, West Virginia: $111 \mathrm{p}$.

Schagerl M., 1991 - Die Algen der Lampenflora in der Hermannshöhle bei Kirchberg/Wechsel (Niederösterreich). Verhandlungen der ZoologischBotanischen Gesellschaft in Österreich, 128: 83-106.

Selvi B. \& Altuner Z., 2007 - Algae of Ballica Cave (Tokat-Turkey). International Journal of Natural and Engineering Sciences, 1: 99-103.

Škaloud P., 2009 - Species composition and diversity of aero-terrestrial algae and cyanobacteria of the Borec Hill ventaroles. Fottea, 9: 65-80.

Skuja H., 1970 - Alghe cavernicole nelle zone illuminate delle Grotte di Castellana (Murge di Bari). Le Grotte d'Italia, Ser. 4, 2: 193-202. 
Smith E.M. \& Benner R., 2005 - Photochemical transformations of riverine dissolved organic matter: effects on estuarine bacterial metabolism and nutrient demand. Aquatic Microbial Ecology, 40: 37-50. http://dx.doi.org/10.3354/ame040037

Smith T. \& Olson R., 2007 - A taxonomic survey of lamp flora (algae and cyanobacteria) in electrically lit passages within Mammoth Cave National Park, Kentucky. International Journal of Speleology, 36: 105-114. http://dx.doi.org/10.5038/1827-806X.36.2.6

Soininen J. \& Könönen K., 2004 - Comparative study of monitoring South-Finnish rivers and streams using macroinvertebrate and benthic diatom community structure. Aquatic Ecology, 38: 63-75.

http://dx.doi.org/10.1023/B:AECO.0000021004.06965.bd

Souffreau C., Vanormelingen P., Verleyen E., Sabbe K. \& Vyverman W., 2010 - Tolerance of benthic diatoms from temperate aquatic and terrestrial habitats to experimental desiccation and temperature stress. Phycologia, 49: 309-324. http://dx.doi.org/10.2216/09-30.1

Souffreau C., Vanormelingen P., Van de Vijver B., Isheva T., Verleyen E., Sabbe K. \& Vyverman W., 2013 Molecular evidence for distinct Antarctic lineages in the cosmopolitan terrestrial diatoms Pinnularia borealis and Hantzschia amphioxys. Protist, 164: 101-115. http://dx.doi.org/10.1016/j.protis.2012.04.001

Šramková K. \& Kováčik L., 2005 - Výskyt cyanobaktérii a rias $v$ nárastoch "lampenflóry" $v$ šiestich spristupnených jaskyniach na Slovensku. Occurrence of cyanobacteria and algae in growths of lampflora in six show caves of Slovakia. Bulletin Slovenskej Botanickej Spoločnosti, 27: 17-21.

St. Clair L.L. \& Rushforth S.R., 1976 - The diatoms of Timpanogos Cave National Monument, Utah. American Journal of Botany, 63: 49-59.

http://dx.doi.org/10.2307/2441667

St. Clair L.L., Rushforth S.R. \& Allen J.V., 1981 - Diatoms of Oregon Caves National Monument, Oregon. Great Basin Naturalist, 41: 317-332.

Stal L.J., 2000 - Cyanobacterial mats and stromatolites. In: Whitton B.A. \& Potts M. (Eds.) - The Ecology of the Cyanobacteria: Their Diversity in Space and Time. Dordrecht, Kluwer Academic Publishers: 61-120.

Stark N., 1969 - Microecosystems in Lehman Cave, Nevada. National Speleological Society Bulletin, 31: 73-81.

Stynes D.J., 1999 - Approaches to Estimating the Economic Impacts of Tourism: Some Examples. Michigan State University, USA, 18 p.

Suba E., 1957 - Die Algen der Palvölgyer Höhle in Ungarn. Verhandlungen der Zoologisch-Botanischen Gesellschaft in Wien, 97: 97-109.

Taylor J.C. \& Lange-Bertalot H., 2013 - Cholnokyella aerophila J.C. Taylor \& Lange-Bertalot gen. et spec. nov. A new diatom (Bacillariophyceae) from sandstone caves in South Africa. Nova Hedwigia, 97: 295-304.

http://dx.doi.org/10.1127/0029-5035/2013/0118

Taylor J.C., Harding W.R. \& Archibald C.G.M., 2007 - An Illustrated Guide to Some Common Diatom Species from South Africa. Water Research Commission, Pretoria, Report TT 282/07, $34+12$ p. \& 178 pls.

Tofilovska S., Wetzel C.E., Ector L. \& Levkov Z., 2014 - Observation on Achnanthes Bory sensu stricto (Bacillariophyceae) from subaerial habitats in Macedonia and comparison with the type material of A. coarctata (Brébisson ex W. Smith) Grunow, A. coarctata var. sinaensis Hustedt and A. intermedia Kützing. Fottea, 14: 15-42.
Uher B., Aboal M. \& Kováčik L., 2005 - Epilithic and chasmoendolithic phycoflora of monuments and buildings in South-Eastern Spain. Cryptogamie Algologie, 26: 275-358.

Urzi C., De Leo F., Bruno L. \& Albertano P., 2010 Microbial diversity in Paleolithic caves: a study case on the phototrophic biofilms of the Cave of Bats (Zuheros, Spain). Microbial Ecology, 60: 116-129.

http://dx.doi.org/10.1007/s00248-010-9710-x

Uzunov B.A., Stoyneva M.P. \& Gärtner G., 2008 - Review of the studies on aero-terrestrial cyanoprokaryotes and algae in Bulgaria with a checklist of the recorded species. II. Phytologia Balcanica, 14: 11-18.

Van Dam H., Mertens A. \& Sinkeldam J., 1994 - A coded checklist and ecological indicator values of freshwater diatoms from The Netherlands. Netherlands Journal of Aquatic Ecology, 28: 117-133. http://dx.doi.org/10.1007/BF02334251

Van de Vijver B. \& Beyens L., 1997 - The epiphytic diatom flora of mosses from Strømness Bay area, South Georgia. Polar Biology, 17: 492-501. http://dx.doi.org/10.1007/s003000050148

Van de Vijver B. \& Cox E.J., 2013 - New and interesting small-celled naviculoid diatoms (Bacillariophyceae) from a lava tube cave on Île Amsterdam (TAAF, Southern Indian Ocean). Cryptogamie Algologie, 34: 37-47. http://dx.doi.org/10.7872/crya.v34.iss 1.2013.37

Van de Vijver B., Frenot Y. \& Beyens L., 2002a- Freshwater diatoms from Île de la Possession (Crozet Archipelago, sub-Antarctica). Bibliotheca Diatomologica, 46: 1-412.

Van de Vijver B., Ledeganck P. \& Beyens L., 2002b - Three new species of Diadesmis from soils of Ile de la Possession (Crozet Archipelago, Subantarctic). Cryptogamie Algologie, 23: 333-341.

VanLandingham S.L., 1965 - Diatoms from Mammoth Cave, Kentucky. International Journal of Speleology, 1: 517-539. http://dx.doi.org/10.5038/1827-806X.1.4.7

VanLandingham S.L., 1966 - Three new species of Cymbella from Mammoth Cave, Kentucky. International Journal of Speleology, 2: 133-136. http://dx.doi.org/10.5038/1827-806X.2.1.11

VanLandingham S.L., 1967 - A new species of Gomphonema (Bacillariophyta) from Mammoth Cave, Kentucky. International Journal of Speleology, 2: 405406. http://dx.doi.org/10.5038/1827-806X.2.4.13

Vanormelingen P., Verleyen E. \& Vyverman W., 2008 - The diversity and distribution of diatoms: from cosmopolitanism to narrow endemism. Biodiversity and Conservation, 17: 393-405.

http://dx.doi.org/10.1007/s10531-007-9257-4

Vidal Romaní J.R., Sanjurjo Sánchez J., Vaqueiro M. \& Fernández Mosquera D., 2010 - Speleothems of granite caves. Comunicações Geológicas, 97: 71-80.

Vinogradova O.N. \& Mikhailyuk T.I., 2009 - Algal flora of the caves and grottoes of the National Nature Park "Podilsky Tovtry" (Ukraine). International Journal on Algae, 11: 289-304.

http://dx.doi.org/10.1615/InterJAlgae.v11.i3.80

Watson J., Hamilton-Smith E., Gillieson D. \& Kiernan K., 1997 - Guidelines for Cave and Karst Protection. Cambridge: International Union for the Conservation of Nature and Natural Resources. 53 p.

Wehr J.D. \& Sheath R.G., 2003 - Freshwater Algae of North America: Ecology and Classification. Academic Press, San Diego - London, 918 p.

Zammit G., Billi D., Shubert E., Kaštovský J. \& Albertano P., 2011 - The biodiversity of subaerophytic phototrophic biofilms from Maltese hypogea. Fottea, 11: $187-201$. 